Ethnic Stratification and the Equilibrium of Inequality:

Ethnic Conflict in Post-colonial States

Manuel Vogt

13,937 words 


\section{Acknowledgments}

The author wishes to thank Lars-Erik Cederman, Carles Boix, Paul Huth, Nils-Christian Bormann, Dan Siegel, Matthijs Bogaards, Tom Pavone, Mark Beissinger, Simon Hug, as well as three anonymous reviewers of the journal for their valuable comments and suggestions. I would also like to express my gratitude to the participants of the Race, Ethnicity, and Identity workshop at Princeton University and the University of Maryland colloquium where I presented this work. The data used in this article can be accessed on the journal's replication website. 
Manuel Vogt

ETH Zürich

vogt@icr.gess.ethz.ch 


\title{
Ethnic Stratification and the Equilibrium of Inequality:
}

\section{Ethnic Conflict in Post-colonial States}

\author{
Manuel Vogt
}

Why are ethnic movements more likely to turn violent in some multiethnic countries than in others? Focusing on the long-term legacies of European overseas colonialism, this article investigates the effect of distinct ethnic cleavage types on the consequences of ethnic group mobilization. It argues that the colonial settler states and other stratified multiethnic states are characterized by an equilibrium of inequality, in which historically marginalized groups lack both the organizational strength and the opportunities for armed rebellion. In contrast, ethnic mobilization in the decolonized states and other segmented multiethnic societies is more likely to trigger violent conflict. The paper tests these arguments in a global quantitative study from 1946 to 2009, using new data on the linguistic and religious segmentation of ethnic groups. The results confirm that the extremely unequal colonial settler states experience less violence than the decolonized states and other multiethnic countries. Beyond the comparison of post-colonial states, ethnic conflict is generally more likely the more segmented and less hierarchically structured multiethnic states are. Specifically, stable between-group hierarchies reduce the risk of governmental conflict, whereas segmentation only affects secessionist violence. 
On January 25, 2009, the Bolivian people approved a new constitution that significantly enhances the rights of the country's indigenous people. After the election of Evo Morales as the country's first indigenous president in 2005 , the enactment of the controversial new constitution marked another high point of ethno-political mobilization in Bolivia. Yet, despite considerable polarization in the run-up to the referendum, the ballot took place in a "peaceful climate amidst high participation."

According to much of the academic literature, the Bolivian scenario of unrestrained ethnic politics in a poor and ethnically divided country should constitute a recipe for chaos and civil violence. ${ }^{2}$ Indeed, ethnicity has been a defining feature of the majority of civil conflicts since World War II. ${ }^{3}$ Especially when they take the form of secessionist or irredentist movements, the negative externalities of these conflicts go beyond individual states, unsettling the stability of the international system. ${ }^{4}$ Admonitory examples of the relationship between ethnic mobilization and civil violence abound: from the violent dissolution of Yugoslavia to the 26-year-long Tamil insurgency in Sri Lanka. This begs the question: why did some states, such as Bolivia, that have seen large-scale ethnic mobilization in the last decades, escape the perilous consequences of ethnic competition? Why did the Civil Rights Movement in the United States of America (USA) not degenerate into a violent struggle, as, for example, the Basque nationalist movement, despite the

${ }^{1}$ According to UN Secretary-General Ban Ki-moon, cited in EFE, 27 January 2009, and reproduced by soitu.es (available at http://www.soitu.es/soitu/2009/01/27/info/1233091485_007369.html. Accessed 4 May 2016).

${ }^{2}$ Collier 2009; Horowitz 1985; Rabushka and Shepsle 1972; Reilly 2006.

${ }^{3}$ Denny and Walter 2014; Gurr et al. 1993.

${ }^{4}$ Saideman 1997; Shelef 2015. 
call by radical organizations for "an all-black nation state?" $\mathrm{Or}$, expressed in more general terms: why is ethnic mobilization more dangerous in some multiethnic countries than in others?

Focusing on the long-term legacies of European overseas colonialism, this article argues that violent inter-group conflict is least likely under conditions of profound, historically determined stratification. In contrast, ethnic mobilization is more likely to trigger violent conflict the more segmented ethnic groups are. In the way I use the term here, ethnic stratification is related to what has been termed "ranked ethnic systems" in the literature. ${ }^{6}$ It implies two characteristics of ethnic groups' relation to each other. First, they are positioned in a stable power hierarchy with one ethnic group historically dominating state power to the continuing exclusion of other groups. Second, ethnic groups have become embedded within the same socio-economic and cultural institutions. This latter condition is what I call ethnic groups' social integration. It is the opposite of social segmentation, i.e. when groups live within the same polity as separate subsocieties, featuring distinct, relatively independent social systems. Hence, countries in which ethnic groups are both hierarchically organized and socially integrated are considered stratified systems.

I argue that ethnic stratification produces what I call an "equilibrium of inequality," in which peaceful contention emerges as the most viable strategy for historically marginalized groups. This equilibrium of inequality is produced by four main causal mechanisms. First, high between-group inequality limits the material resources available to marginalized groups and, thus, their organizational strength. Second, social integration decreases ethnic groups' distinc-

\footnotetext{
${ }^{5}$ Marable 2007, 54.
}

${ }^{6}$ See, e.g., Blanton, Mason, and Athow 2001; Horowitz 1985; Mason 2003. Without using the same term, other scholars have also examined ethnic stratification; see e.g. Hechter 1975; Smith 1969. 
tiveness and internal cohesion, which reduces the strength of collective mobilization. While this lack of organizational strength affects collective action in general, it becomes particularly consequential in the case of costly and high-risk forms of it, such as armed rebellion. Third, stable between-group hierarchies make coercion on the part of the ruling regime more effective. This prevents the emergence of viable military challenges, especially to central state power. Finally, high social integration decreases the opportunities for armed rebellion, even in the face of profound inequality, by increasing interdependence between groups. This fourth mechanism operates most strongly against secessionist attempts.

Hence, this argument deviates from grievances-based theories of ethnic conflict, which expect the conflict-fueling effect of ethnic mobilization to be strongest in those countries that exhibit the most profound inter-group inequalities. ${ }^{7}$ According to these works, the more severe ethnic inequality is, the stronger the collective grievances on the part of the marginalized groups, and the more likely violent resistance. Some scholars also explicitly or implicitly assume that ethnic groups as such generally possess similar mobilization capacities and face similar opportunities to rebel. ${ }^{8}$ Thus, these approaches usually treat the political opportunity structure and groups' mobilization capacity, on the one hand, and ethnic inequality, on the other hand, as alternative explanations for civil conflict. Moreover, despite their groundbreaking insights, previous works on ethnic stratification and ranked ethnic systems did not offer any theoretical and empirical assessment of the origins of ranked ethnic systems nor of the relationship between different ethnic systems and the likelihood of violent conflict at the global level. In fact, Horowitz

${ }^{7}$ See, e.g., Cederman, Gleditsch, and Buhaug 2013; Stewart 2008; Wimmer, Cederman, and Min 2009.

${ }^{8}$ Denny and Walter 2014, 200, 202; Esteban and Ray 2008; Robinson 2001. The latter two studies contrasted ethnicity as a unidimensional concept with class. 
argued that ranked and unranked ethnic systems are equally prone to conflict, albeit of different forms. ${ }^{9}$ In contrast, this study specifies the historical origins of distinct ethnic cleavage types in the majority of today's states and theorizes their consequences for ethnic groups' organizational strength and their opportunities to rebel. Thus, it embeds the concept of ethnic systems in a broader theory of colonial state-building, inequality, and political violence in the contemporary world.

European overseas colonialism has decisively shaped the type of ethnic cleavages that we observe today. The colonial settler states that became independent under the continuing rule of the European settlers (or their descendants) constitute archetypical cases of stratified ethnic systems. I distinguish these settler states from what I call the "decolonized states," where independence resulted in self-rule by the formerly colonized people. The retreat of the colonizers - and, thus, the breakdown of the primary hierarchy - and the legacy of colonial policies of "divide and rule" have made the decolonized states paradigmatic examples of segmented multiethnic states. Therefore, the colonial settler states and the decolonized states constitute the two sets of cases where the empirical implications of my theoretical argument should be most evident.

Using new data on the linguistic and religious segmentation of ethnic groups, I test my arguments in a global quantitative study of all multiethnic states from 1946 to 2009. The empirical results confirm, first, that the extremely unequal colonial settler states experience less violent ethnic conflict than the decolonized states and other multiethnic countries. Second, beyond the

${ }^{9}$ Horowitz 1985, 22, 30. Similarly, Mason claimed that when inter-group conflict in ranked ethnic systems occurs it should be particularly violent; see Mason 2003, 91. Guelke also argues that in societies composed of dominant and subordinate groups - and, in particular, of settlers and natives - ethnic divisions are especially prone to lead to violent political conflict; see Guelke 2012. 
comparison of post-colonial states, ethnic conflict is generally more likely the more segmented and less hierarchically structured multiethnic states are. Third, in line with the theory, stable between-group hierarchies reduce the risk of governmental conflict, whereas segmentation only affects secessionist conflicts. Additional robustness tests indicate that the theorized equilibrium of inequality holds when examining the immediate post-independence period of the settler states and when controlling for the identity of colonial powers, democratic freedoms, natural resource production, as well as different measures of state strength. I also provide evidence for the exogeneity of my main independent variables by accounting for those factors that may have affected how colonialism ended.

Hence, beyond the far-reaching international consequences of ethnic (and, especially, secessionist) conflict, my study also highlights its historical international sources. Previous studies have already pointed out how international factors, such as geopolitical competition, colonialism, or military mobilization affected state formation, ${ }^{10}$ the emergence of democratic political institutions, ${ }^{11}$ and countries' economic development. ${ }^{12}$ The results of this study suggest that their present-day conflict-proneness, too, greatly depends on the historical structure of ethnic group relations resulting from specific colonial legacies.

\footnotetext{
${ }^{10}$ See, e.g., Blaydes and Paik 2016.

${ }^{11}$ See, e.g., Bernhard, Reenock, and Nordstrom 2004.

${ }^{12}$ Acemoglu and Robinson 2012; Lange, Mahoney, and vom Hau 2006.
} 


\section{European Colonialism, State Formation, and Ethnic Stratification}

European overseas colonialism is the instance of colonial expansion that has most directly molded the contemporary international state system, creating almost two thirds of all current multiethnic states. ${ }^{13}$ I distinguish between two specific classes of European ex-colonies: the colonial settler states and the decolonized states, which constitute the two sets of cases where the empirical implications of my theoretical argument should be most evident. The colonial settler states are those states that became de jure or de facto independent under the continuing rule of the European settlers (or their descendants) over the indigenous population. Thus, codified as racial distinctions, the colonial hierarchies - composed of the white rulers, the subjugated aboriginal populations and (in the case of the Americas) the imported African slaves and their descendants - were directly carried over to the post-independence period. This is true for both Latin American and English settler colonies. Although the latter have been characterized by more political equality among the European settlers ${ }^{14}$ their institutions are based on the same inequality between the settlers and the racially defined others as in Latin America.

Moreover, the conquered groups in the colonial settler states have become incorporated into the political and economic institutions (legal order, organization of land ownership, political party system, etc.) set up by the European settlers. Through linguistic and religious assimilation they have also adopted the settlers' cultural institutions to a certain degree. For instance, African

\footnotetext{
${ }^{13}$ Following Weber 1976[1922], ethnicity can be defined as a subjectively experienced sense of commonality based on a belief in common ancestry and shared culture. This belief is usually nurtured by supposedly innate traits that are shared by members of a group, such as language, religion or certain phenotypical features; see Horowitz 1985, 51-52.

${ }^{14}$ See Acemoglu and Robinson 2012; Lange, Mahoney, and vom Hau 2006.
} 
Americans in the USA, Afro-Brazilians in Brazil, or indigenous people in El Salvador and Honduras all speak the language of the dominant group of their states. Likewise, in Guatemala and Ecuador, indigenous people have become incorporated into the religious institutions set up by their conquerors. As a result, ethnic groups in the colonial settler states are socially highly integrated. These states thus constitute archetypical cases of stratified or "ranked" ethnic systems, according to my definition.

In contrast, the decolonized states are countries that were ruled by a European power during the period of overseas colonialism but became independent under the self-rule of the formerly colonized people. These were generally resource colonies in Asia, Africa, and a few territories in the Caribbean and the Pacific. While their independence in the $20^{\text {th }}$ century was equivalent to decolonization, their ethnic cleavages were also profoundly shaped by European colonialism. In order to control the subjugated indigenous populations the colonial rulers turned to policies of “divide and rule," consciously fostering linguistic, religious, and tribal distinctions between groups. Colonial administrative penetration - especially tax and labor policies, as well as educational institutions - strengthened these segmented ethnic identities over time. ${ }^{15}$ As a consequence, independence and decolonization marked the transformation of racially ranked societies to congregations of "separate subsocieties,"16 assembled within a common political territory.

${ }^{15}$ Posner 2005; Vail 1989. It is true that by introducing their own languages to the colonies' administrative and educational systems, the colonizers also provided the decolonized states with a lingua franca. Yet, rather than providing the basis for group identities, these colonial languages serve as a tool of class differentiation within ethnic groups, separating the elites from the masses.

${ }^{16}$ Horowitz 1985, 36. 
For instance, Sunnis, Shiites, and Kurds in Iraq; Baluchis, Pashtuns, Punjabis, and Sindhis in Pakistan; the Muslim Fulani, Christian Beti, and Christian, but Anglophone Bakweri groups in Cameroon; and the Buddhist Sinhalese and Hindu Tamils in Sri Lanka are all assembled within a common political territory shaped by European colonizers, but they remain divided into distinct, relatively independent social systems. Moreover, although colonial favoritism towards specific groups was quite common, with the retreat of the colonizers the primary hierarchy disappeared. Therefore, ethnic segmentation, rather than stratification, is the most common ethnic cleavage type in these states. ${ }^{17}$

It is important to note that European colonial rule took very brutal forms in both types of European ex-colonies. Yet, while the intense, relatively short-term quest for natural resources also resulted in appalling regimes of colonial exploitation in Africa, ${ }^{18}$ the external and internal colonization of the Americas occurred over a longer period of time. The genocidal impact of colonial conquest, labor exploitation, and imported diseases significantly decimated the indigenous people in the Americas, to the degree that they now constitute (sometimes small) minorities in almost all states. Nevertheless, since at least the 1970s, a new wave of ethnic group mobiliza${ }^{17}$ The most prominent potential exceptions are probably Rwanda, Burundi, and India. Yet, although the Hutu and Tutsi in Rwanda and Burundi have been considered ranked ethnic groups, whatever hierarchy existed between them before and during colonialism was definitely altered by the retreat of the colonizers. It is indicative that the distribution of political power between Hutu and Tutsi and the victims of ethnic persecution were precisely opposite in the two countries after independence. While the Indian caste system constitutes a paradigmatic case of a ranked ethnic system, post-colonial India is characterized by a multitude of alternative ethnic divisions that mitigate, or even contradict, the caste hierarchies; see Chandra 2005.

${ }^{18}$ Young 1994. 
tion has gained traction even in those colonial settler states with very small minority populations, such as Paraguay or El Salvador. ${ }^{19}$ In many cases, such mobilization occurred under an umbrella political identity at the national level, as, for example, in the case of indigenous people in Argentina or African Americans in the USA; in other cases, it was propelled by distinct ethnic groups, such as the Garifuna in Honduras or the Miskito in Nicaragua. ${ }^{20}$

Finally, both the colonial settler states and the decolonized states can be distinguished from those countries in Europe and (less commonly) Asia that were never subject to European overseas colonialism. In most of these cases, state formation was promoted by a core ethnic group that is now recognized as the titular group of the respective state. Many of them emerged out of larger empires, such as the Ottoman Empire or the Soviet Union. Although some of them also contain significant numbers of settlers from these former occupying powers (such as the Russians in Latvia, Belarus, or Turkmenistan), the crucial difference to the colonial settler states is that the independence of these states was promoted by, and attained under the rule of, an "indigenous" state-building group. As will be shown in Figure 2 below, this type of state building has also led to stable ethnic hierarchies in some cases. ${ }^{21}$ Yet, the core group at the center and the geographically concentrated linguistic and/or religious minorities often constitute relatively seg-

\footnotetext{
${ }^{19}$ See, e.g., Vogt Forthcoming.

${ }^{20}$ The EPR-ETH dataset used in this study combines indigenous groups in the Americas into one single politically relevant ethnic group where they underwent a joint process of political mobilization at the national level. Only groups that experienced historically distinct paths of mobilization are treated as separate politically relevant groups. Since the statistical analyses of this study rely on country-level indicators, these differences do not affect my empirical results.

${ }^{21}$ See also Hechter 1975; Wimmer 2002.
} 
mented subsocieties, quite similar to those in the decolonized states. In those cases where state building remained unfinished and the state was never able to firmly penetrate its whole territory, as, for example, in Afghanistan, ethnic groups are even more likely to constitute independently functioning subsocieties today. Table 1 shows the classification of all countries included in the study. $^{22}$

[Table 1]

\section{Ethnic Movements and Inter-group Violence}

Following Tilly, the term "political mobilization" can be broadly defined as "the process by which a group goes from being a passive collection of individuals to an active participant in public life."23 I argue that whether ethno-political mobilization triggers violent inter-group conflict greatly depends on the historically determined ethnic cleavage types, which shape both the organizational strength of group mobilization and the "structure of political opportunities." 24 In

${ }^{22}$ These are all countries in which ethnicity has been politically relevant, according to the EPR-ETH dataset (see the explanations in the data section below). Countries that do not meet this definition, such as Haiti or Ireland, are thus excluded from the empirical analyses below. To determine the colonial origins of states, I largely followed Bernhard, Reenock, and Nordstrom 2004; and Hensel 2014, with the exceptions of those cases that I define as colonial settler states.

${ }^{23}$ Tilly 1978, 69.

${ }^{24}$ McAdam 1982, 40. The two most prominent studies emphasizing the role of opportunities in the recent civil war literature are probably Fearon and Laitin 2003, and Collier and Hoeffler 2004. However, their 
particular, I focus on two properties of cleavage types: the extent of between-group hierarchization and the degree of ethnic groups' social integration. In the colonial settler states and other stratified ethnic systems, stable between-group hierarchies and a high degree of social integration produce an "equilibrium of inequality," in which the marginalized groups lack both the organizational strength and the opportunities for armed rebellion. As a consequence, while ethnicity is not necessarily less politicized in these states than in other countries peaceful ethno-political contention emerges as the most viable strategy for the subordinated groups. In contrast, ethnic mobilization in the decolonized and other segmented states is more likely to trigger violent conflict.

\section{Resource Mobilization, Group Identities, and Organizational Strength}

Stable between-group hierarchies limit the organizational strength of historically marginalized groups' mobilization and thus reduce the likelihood of violent insurgencies. Any social movement must control and mobilize a certain amount of resources (for example, money, facilities, and labor) in order to carry out collective action. ${ }^{25}$ While this argument applies to collective action in general, it is especially true for violent challenges to the state, which are costlier in material terms and entail higher economic opportunity costs than other forms of contentious acin this study.

${ }^{25}$ McCarthy and Zald 1977; Tilly 1978. 
tions. ${ }^{26}$ The costlier and riskier collective action is, the more difficult it is to organize and, thus, the more resources are needed.

Elite members of groups play a crucial role in mobilizing these resources. ${ }^{27}$ Yet, because of the entrenched between-group hierarchies (which tend to extend to the economic realm), the elite of the historically marginalized groups in stratified ethnic systems is often too small and too weak to mobilize the necessary resources. At the same time, the material incentives of these leaders to be co-opted and sacrifice collective struggles in favor of (further) individual advancement are also particularly high. As a result, the material co-option of a handful of group leaders is often enough to undermine mobilization and, thus, prevent rebellion. If, in addition, average group members are poor, they will not be able to financially contribute to, or supply the necessary labor for, organizational processes.

In contrast, where between-group hierarchies are less stable, intra-ethnic stratification should be more pronounced. In other words, each ethnic group in these states usually has its own elite and poorer stratum, which facilitates the provision of the necessary resources for ethnic rebellion. For example, in decolonized Nigeria, each of the main ethnic groups had their own national leaders that were able to organize the non-elite group members into powerful political organizations, which subsequently served to mobilize individuals for violence. ${ }^{28}$ As Esteban and Ray note, "[s]uch inequalities possess their own perverse synergy. Specifically, the rich within a

\footnotetext{
${ }^{26}$ This applies, above all, to the type of violence examined in this article: civil conflict. As I will discuss in the concluding section, the causal mechanisms presented here may not apply equally to other forms or strategies of inter-group violence.

${ }^{27}$ Esteban and Ray 2008, 2186.

${ }^{28}$ Diamond 1988.
} 
group can supply the resources for conflict, while the poor supply conflict labor" [emphasis in the original]. ${ }^{29}$

The organizational strength of group mobilization is also a function of the degree of ethnic groups' social integration. By the social integration or segmentation of ethnic groups, I refer to the extent to which groups are embedded within the same socio-economic and cultural institutions. Institutions can be defined as established sets of norms, values, and modes of action and interaction that govern particular aspects of social life. ${ }^{30}$ Specifically, social integration reduces the strength of collective mobilization by decreasing ethnic groups' distinctiveness and internal cohesion. Distinct and cohesive collective identities make group boundaries more evident and, thus, operate against cross-cutting membership in political organizations. They also make individual assimilation more difficult. ${ }^{31}$ The more integrated groups are, the less distinct and cohesive their group identities and, as a consequence, the easier it is for individuals to cross group boundaries and seek political or economic advancement as individuals. This individual "escape hatch" hampers the collective political organization of groups as a whole. In contrast, the more segmented groups are, the more distinct and cohesive their collective identities and, consequently, the greater their potential for political organization.

Again, while this mechanism affects ethnic mobilization in general, it becomes particularly consequential in the case of costly and high-risk collective action, such as armed revolt, because

${ }^{29}$ Esteban and Ray 2008, 2186. It is important to emphasize again that in contrast to my argument, Esteban and Ray make this observation for ethnic groups in general, without distinguishing between different cleavage types.

${ }^{30}$ Radcliffe-Brown 1965.

${ }^{31}$ Gurr et al. 1993, 126-127; Madrid 2012. 
under such conditions individuals have even greater incentives to cross group boundaries (if provided with the opportunity). ${ }^{32}$ In other words, the centrifugal forces that affect collective action are greater the riskier and costlier such collective action gets, requiring more organizational strength to keep individuals together and prevent them from defecting.

\section{Coercion, Interdependence, and the Opportunities for Armed Rebellion}

Next to the organizational strength of group mobilization, the political opportunity structure plays a crucial role in explaining ethnic group rebellion. Stable between-group hierarchies affect the political opportunity structure by making coercion on the part of the ruling regime more effective. Specifically, the unequal distribution of the political and socio-economic instruments of power in the colonial settler states provides the dominant ethno-class with a wide array of coercive measures against challenging groups. These range from monitoring the subordinated group(s) and economic coercion (for example, the denial of access to resources, boycotting the labor of members of these groups for certain periods of time, etc.) to outright violent repression by the unilateral use of military force. ${ }^{33}$ The dominant ethno-class can also dissuade the subordinated groups from challenging the status quo through the clientelistic distribution of resources and through policies of divide and rule.

Between-group hierarchies should be most consequential for armed revolts directed against the state center. State power is usually strongest at its center and, thus, coercion works most effectively against direct challenges to governmental power. In contrast, if marginalized ethnic

\footnotetext{
${ }^{32}$ Laitin 2000.

${ }^{33}$ Mason 2003, 86-91.
} 
groups inhabit territorial pockets where the political authority of the dominant group is comparatively weak, they might be able to avoid repression and challenge the state in their own territory. As a consequence, group hierarchization should have a stronger deterring effect on conflicts over government than on territorial (or secessionist) conflicts.

These arguments obviously apply to any type of multiethnic society. The more profound political and economic inequality between ethnic groups is, the more adverse the political opportunity structure facing the marginalized group(s). Yet, due to their distinct historical legacy, the ranked colonial settler states are particularly likely to feature such stable between-group hierarchies. Only in the case of an extremely unequal demographic balance, when the subordinated groups form an overwhelming majority - as, for instance, in Zimbabwe and South Africa - coercion becomes too costly (or even impossible) to sustain.

High social integration also narrows the political opportunity structure. The more integrated ethnic groups are, the higher their interdependence. In the colonial settler states and other highly stratified ethnic systems, individual members of the dominant and subordinated groups are often embedded in tightly knit, hierarchically structured relationships, taking on a patronclient, employer-worker, officer-soldier, or similar format. This social and economic interdependence decreases both the opportunities and incentives of the marginalized groups for sustained violence. For instance, the status of the small circle of elites of subordinated groups in the colonial settler states usually depends on their adhesion to the dominant culture and their access to the resources of the ruling group. ${ }^{34}$ Hence, while they may try to peacefully mobilize members of their ethnic group to enhance their political leverage, these elites will have little interest in a

${ }^{34}$ Consider the example of the indigenous elite in Quetzaltenango, Guatemala, described by Grandin 2000. 
violent escalation of political conflicts. Conversely, the dominant ethno-class usually depends on the labor supply (for example, for food production) by the subordinated groups. Thus, high degrees of social integration and the associated interdependence of ethnic groups should generally decrease the likelihood of violent inter-group conflict. In contrast, ethnic groups in highly segmented societies are more likely to constitute (and perceive themselves as) self-standing communities able to exist as separate entities.

Of course, geography is an important aspect of social integration. Because socio-economic and cultural institutions are often adopted across groups as a result of spatial proximity, ethnic groups in segmented societies are also more likely to be geographically segmented. ${ }^{35}$ Therefore, they usually possess the separate territorial bases that facilitate the coordination of insurgent actions, especially for secessionist movements. ${ }^{36}$ As discussed above, this situation is common for ethnic groups in the decolonized states, which often inhabit distinct geographic zones, as, for instance, the Kurds in Iraq or the Diola in Senegal. It also applies to many titular nation states with sizeable ethnic minorities, as the examples of the Basque country and the Russian-speaking eastern part of the Ukraine show. In the case of strong collective grievances, ethnic groups in these states are more likely to seek secession than the highly integrated ethno-classes in the colonial settler states.

The comparison of the two classes of post-colonial states leads us to the first hypothesis of this study:

\footnotetext{
${ }^{35}$ Note that when empirically examining the causal mechanisms responsible for the different ethnic conflict rates, I control for the degree of geographic overlap between ethnic groups in order to disentangle the distinct effects of social integration and geography.

${ }^{36}$ Toft 2003; Weidmann 2009.
} 
H1: Colonial settler states are less prone to violent ethnic conflict than decolonized states.

Yet, while the colonial settler states and the decolonized states are archetypical cases of ranked and segmented ethnic systems, respectively, my theoretical arguments about the effect of distinct cleavage types on the likelihood of violent conflict should be applicable to all multiethnic countries. Hence, from the foregoing explanations, three additional hypotheses can be deduced to test the general validity of my theory:

H2: Stable between-group hierarchies decrease the likelihood of violent ethnic conflict.

H3: High social segmentation increases the likelihood of violent ethnic conflict.

H4: High social segmentation increases the risk of territorial conflict, whereas stable group hierarchies decrease the likelihood of governmental conflict.

\section{Alternative Explanations}

Before turning to the empirical analyses, I will address three potential objections to my arguments. First of all, the choice of peaceful, rather than violent, strategies may also depend on the degree of democratic freedom. In democratic systems where groups are more likely to trust the existing regime to address their grievances, peaceful strategies should be more likely. However, the examples of South Africa and the USA under Jim Crow show that even formally functioning democratic systems may systematically disregard demands from specific ethnic groups, 
whether they are expressed through conventional institutional channels or through peaceful protest activities. ${ }^{37}$ In fact, as Gamson famously pointed out, while democratic regimes are designed to take into account and balance the interests of established polity members, they tend to systematically resist (and sometimes actively oppress) the interests of challenging groups. ${ }^{38}$ It is not surprising then that according to previous research, the empirical relationship between democracy and civil conflict is shaky at best. ${ }^{39}$ Nevertheless, countries' level of democracy might certainly play a role and, therefore, will be controlled for in the following quantitative analyses.

Second, as discussed above, the racial minority population in some of the colonial settler states is very small. One could thus argue that these minorities are simply too small to rebel, and/or that violent rebellions of underprivileged groups occur under a different, non-ethnic banner. In this case, the colonial settler states would not be very different from any of the nation states in the Western hemisphere that became ethnically homogenized centuries ago ${ }^{40}$ and are now characterized by a large demographic majority group that is also politically dominant. According to this argument, the theorized equilibrium of inequality is caused entirely by homogeneity, rather than ethnic stratification.

Third, and relatedly, such ethnic homogenization is likely to be associated with a high degree of state consolidation. Cultural homogenization was most likely to occur in states that were able to exert strong administrative power in their territories over a long period of time. Despite

\footnotetext{
${ }^{37}$ Marx 1998.

${ }^{38}$ Gamson 1975.

${ }^{39}$ See, e.g., Vreeland 2008.

${ }^{40}$ Mann 2005.
} 
the political marginalization of the "surviving" ethnic minorities, ${ }^{41}$ such old, consolidated states should be less conflict-prone than younger states. ${ }^{42}$ Thus, from this view, the equilibrium of inequality and the differences between the colonial settler states and the decolonized states would simply be a function of state consolidation. Both of these latter two scenarios suggest that the colonial settler states are a subset of a more general class of consolidated, homogenous countries, implying a causal logic that is distinct from my own theoretical argument. I will address these objections empirically by controlling for state consolidation and ethnic homogeneity in the regression models.

\section{Data and Methodology}

The empirical analysis includes all independent multiethnic countries of the world, covering the time period from 1946 - or the country's year of independence - to 2009. It examines ethnic inequality and civil conflict in three types of multiethnic states: the colonial settler states, the decolonized states, and a residual category composed of non-colonized states and those that became independent from other types of foreign rule (see Table 1 above).

\section{Dependent Variable: Ethnic Civil Conflict}

This study focuses on ethnic violence in the form of civil conflict. The civil war data stem from the UCDP/PRIO Armed Conflicts Dataset where a conflict is defined as a contested incompatibility over government or territory between two parties of which at least one is the govern-

\footnotetext{
${ }^{41}$ Hechter 1975; Mann 2005; Wimmer 2002.

${ }^{42}$ Fearon and Laitin 2003.
} 
ment of a state, resulting in at least 25 battle-related deaths per year. ${ }^{43}$ In accordance with the ACD2EPR dataset, civil conflicts were classified as ethnic if the corresponding rebel organizations both recruited fighters from a particular ethnic group and made public claims on behalf of the group. ${ }^{44}$ Overall, the sample contains 262 civil conflict onsets (about $4 \%$ of all country years), of which 155 were classified as ethnic (2.4\% of all country years).

Yet, in highly stratified societies, class and ethnicity tend to overlap and, thus, inter-group violence may often take on the form of a class conflict without explicit ethnic claims being advanced. ${ }^{45}$ Because this could distort the comparison between the stratified colonial settler states and other multiethnic countries, additional analyses rely on a broader operational definition of ethnic conflict, which classifies civil conflicts as ethnic if the corresponding rebel organizations either recruited fighters from a particular ethnic group or made public claims on behalf of the group. This includes all instances of civil violence where rebel organizations relied heavily on specific ethnic groups without making explicit ethnic demands. Overall, there are 192 civil conflicts (2.9\% of all country years) that conform to this broader definition of ethnic civil conflict.

Finally, hypothesis H4 distinguishes between governmental and territorial conflicts. The UCDP/PRIO Armed Conflicts Dataset defines governmental conflicts as conflicts over regime type, replacement of the central government, or a change of its composition, whereas territorial conflicts are defined as conflicts over the status of a territory within a given state (i.e. secession

\footnotetext{
${ }^{43}$ Gleditsch et al. 2002.

${ }^{44}$ Wucherpfennig et al. 2012.

${ }^{45}$ Horowitz 1985, 30.
} 
or autonomy).$^{46}$ Of the 155 ethnic civil conflicts in the dataset, following the strict definition, 50 qualify as governmental (0.8\% of all country years), and 105 as territorial (1.6\%).

\section{Ethnic Groups and Ethnic Inequality}

To measure the degree of ethno-political inequality, I rely on the Ethnic Power Relations (EPR-ETH) dataset, version 2.0. ${ }^{47}$ Constructed on the basis of an expert survey, EPR-ETH provides information about politically relevant ethnic groups, and their access to executive state power, in all countries of the world with a population, in 1990, of at least $500,000 .{ }^{48}$ Ethnic groups are considered "politically relevant" if at least one political organization has claimed to represent their interests at the national level or if its members are subjected to state-led political discrimination.$^{49}$ Because of its focus on groups that exhibit a minimal level of political mobilization, the EPR data are very well-suited to test my theoretical argument about the distinct consequences of ethnic movements as a function of different ethnic cleavage types. Appendix 1 provides a list of all ethnic groups included in the EPR-ETH dataset by country.

Ethnic groups' access to state power is assessed based on the positions of the political leaders representing these groups, focusing explicitly on executive power and using a roughly ordinal scale composed of three main categories: i) a group controls power alone (group status of monopoly or dominant); ii) shares power with other ethnic groups (either as senior or junior

\footnotetext{
${ }^{46}$ Gleditsch et al. 2002, 619.

${ }^{47}$ Cederman, Wimmer, and Min 2010; Wimmer, Cederman, and Min 2009.

${ }^{48}$ Version 2.0 of the EPR data covers the time period from 1946 to 2009 and can be accessed at http://www.icr.ethz.ch/data/other/epr-2.0.

${ }^{49}$ Cederman, Wimmer, and Min 2010, 99.
} 
partner); or iii) is excluded from executive state power (group status of regional autonomy, powerless, or discriminated). ${ }^{50}$

Previous studies using this dataset have mostly focused on the last category, finding that excluded groups are more likely to rebel than included groups and countries with large excluded ethnic segments of the population are likely to experience civil conflict. ${ }^{51}$ However, there are two crucial distinguishing features among regimes of ethnic exclusion. First, exclusion may be the consequence of one-group ethnic dominance - where all but one ethnic group are excluded from access to national-level executive power - or it may stem from an incomplete power-sharing regime, in which two or more groups share power but exclude some other groups. Second, ethnic exclusion may be more or less persistent over time.

Both of these characteristics are highly relevant for the concept of hierarchization that constitutes a central element of my theoretical argument. Hence, to gauge the degree of group hierarchization, the bivariate analyses use two complementary indicators. The first one is a dominance dummy variable that is based on the category of one-group rule. It takes the value of 1 when an ethnic group controlled power alone in a given country year, being coded as either "dominant" or "monopoly" in EPR-ETH, and 0 otherwise. ${ }^{52}$ Yet, by itself this indicator is not enough to assess the stability of group hierarchies because different ethnic groups may be politically dominant at different points of time. Thus, a second dummy variable records the ethnic

\footnotetext{
${ }^{50}$ See Cederman, Wimmer, and Min 2010, 100-101, for precise definitions of the different power status categories.

${ }^{51}$ See especially Cederman, Gleditsch, and Buhaug 2013; Wimmer, Cederman, and Min 2009.

${ }^{52}$ In contrast to monopoly power, the EPR status of dominant denotes "token" representation of other ethnic groups in the executive, as, for example, an indigenous minister of culture in Guatemala.
} 
power shifts in a country. It is coded as 1 in country years, in which EPR-ETH codes a change in the coalition of the politically included ethnic groups (for example, when a new group became included or when there was a change of senior and junior partners), and as 0 otherwise.

Moreover, the regression analyses rely on a count variable of the consecutive years of onegroup dominance as a continuous measure of group hierarchization. Finally, when examining the casual mechanisms responsible for the different ethnic conflict rates, I also test the impact of ethnic exclusion per se, as analyzed in the aforementioned studies (i.e. independent of ethnic dominance). To this end, I include a continuous indicator of the relative size of all excluded groups as a fraction of the size of all politically relevant ethnic groups in the corresponding regression models.

\section{Social Integration vs. Segmentation of Ethnic Groups}

To empirically capture the idea of socio-economic and cultural "embeddedness" of ethnic groups, implied by my definition of integration and segmentation, I rely on group-based indicators of ethnic groups' linguistic and religious overlap. These indicators stem from the new EPRED dataset, ${ }^{53}$ which identifies the precise "cultural content" of all ethnic groups included in the EPR-ETH dataset by indicating the languages group members speak and the religions they practice. For each group, the three largest linguistic and religious fragments (in terms of their share of the total group population) are reported.

Both indicators of linguistic and religious segmentation were computed in the same way, by calculating group-level differences, which were subsequently aggregated to the country level.

${ }^{53}$ Bormann, Cederman, and Vogt Forthcoming. 
Appendix 2 describes the procedure in more detail and provides a real-world example. Put simply, the measures indicate from how many other groups in the country, on average, any ethnic group is linguistically (or religiously) distinct. Both indicators range from 0 (complete integration) to 1 (complete segmentation). For example, Uruguay and Rwanda are linguistically highly integrated states, in which all groups share one common language (Spanish and Kinyarwanda, respectively), whereas Belgium is an example of high linguistic segmentation. Importantly, the two indicators do not correlate with each other ( $\mathrm{r}=0.00 ; p=0.84)$, justifying their treatment as two distinct expressions of ethnic groups' social integration.

Note that I refrain from drawing on the commonly used fractionalization indices because they refer to the likelihood of individuals to be from different ethnic groups. Moreover, although there are important divisions within ethnic groups, existing fractionalization data treat them as homogenous, mutually exclusive entities. As a result, these datasets are unable to measure the degree of cultural (for example, linguistic or religious) overlap between groups, which is indicative of their social integration or segmentation.

\section{Control Variables}

The control variables attempt to capture those factors that could potentially have an impact on both ethnic inequality and ethnic civil violence, such as the level of democracy, economic development, state age, country-level ethnic homogeneity, and the prior occurrence of ethnic violence. The latter is captured by the number of previous ethnic conflicts in a given country. I use the Polity index ${ }^{54}$ and a GDP per capita variable from the Penn World Table, version $7.0,{ }^{55}$ to

${ }^{54}$ Gurr, Jaggers, and Moore 1989. 
assess the level of democracy and economic development. Moreover, an additional robustness test employs a democracy indicator from the new V-Dem dataset, version $6.1,{ }^{56}$ instead of the Polity index. State age is measured with a count variable of the number of years since independence, based on the independent-states dataset by Gleditsch and Ward ${ }^{57}$ Country-level ethnic homogeneity is proxied by the size of the single largest ethnic group in a country as a fraction of the country's total population, according to the EPR-ETH dataset. I also include a total country population variable, drawn from the Penn World Table, in all models.

In additional robustness tests, I examine the plausibility of a number of other potential alternative explanations. First, previous studies of the long-term effects of colonial legacies focused on the identity of the colonizers ${ }^{58}$ whereas my own argument is centered on the (ethnoracial) identity of the promoters and beneficiaries of independence. To compare the explanatory weight of the two alternative approaches with respect to violent ethnic conflict, I include colonial power dummies, taken from Hensel. ${ }^{59}$ Second, post-colonial violence may be more likely if independence was achieved through violent struggle. Therefore, an additional robustness model includes a violent-independence dummy variable based on the same data source. Third, as an alternative to my measure of state consolidation introduced above, I test the effect of a state's extractive capacity, measured by the tax ratio (i.e., a state's tax revenue as a percentage of GDP).

\footnotetext{
${ }^{55}$ Heston, Summers, and Aten 2011.

${ }^{56}$ Coppedge et al. 2015.

${ }^{57}$ Gleditsch and Ward 1999.

${ }^{58}$ E.g., Bernhard, Reenock, and Nordstrom 2004; Lange, Mahoney, and vom Hau 2006.

${ }^{59}$ Hensel 2014.
} 
These data are taken from Thies. ${ }^{60}$ Fourth, particular colonial legacies may be related to distinct economic profiles in terms of natural resource production - which, in turn, may have an effect on conflict likelihood. Hence, another robustness model controls for countries' per capita oil and diamond production quantities (the two resource types that figure most prominently in conflict studies), based on data from Humphreys. ${ }^{61}$

Furthermore, when testing the postulated causal factors responsible for the equilibrium of inequality (between-group hierarchy and social integration), I take into account the impact of ethnic groups' settlement patterns, i.e. the degree of their geographic overlap. For this purpose, I employ a count variable of the number of ethnic groups that live dispersed throughout the country's territory, taken from the GeoEPR-ETH dataset. ${ }^{62}$ The more groups that live dispersed throughout the country, the more geographic overlap should exist.

Finally, since my analysis examines the effect of distinct colonial legacies by comparing the colonial settler states with the decolonized states and other multiethnic countries, I assess potential concerns of endogeneity with regard to these state type indicators. This exogeneity test accounts for those factors that may have affected how colonialism ended: physical accessibility, historical disease environment, and historical resource attractiveness of countries, drawing on

\footnotetext{
${ }^{60}$ Thies 2010.

${ }^{61}$ Humphreys 2005.

${ }^{62}$ Wucherpfennig et al. 2011. The GeoEPR-ETH dataset defines dispersed groups as groups whose members do not inhabit any particular region or that are migrant (e.g., nomadic groups).
} 
data on countries' proximity to a coast,${ }^{63}$ logged settler mortality rates,${ }^{64}$ and soil fertility, ${ }^{65}$ respectively. Appendix 3 provides summary statistics of the main independent variables.

\section{Statistical Estimation}

The study draws on bivariate analyses and logistic regression models of ethnic conflict onset to test the theoretical argument. In the logit models, the unit of analysis is the country year, and the data are formatted as a pooled panel with yearly time intervals. Because civil conflict onsets are very infrequent, I rely on logistic regressions for rare events data, as proposed by King and Zeng. ${ }^{66}$ To account for temporal dependence within countries, the models contain a cubic polynomial of ethnic-peace years. ${ }^{67}$ Moreover, because the different observations within a country are likely to be correlated, the result tables below report country-clustered Huber-White standard errors. ${ }^{68}$

${ }^{63}$ Nunn and Puga 2012. This is the average distance, in thousands of kilometers, to the closest coast in each country.

${ }^{64}$ Acemoglu, Johnson, and Robinson 2001. The indicator is constructed as the annualized deaths per thousand mean strength among soldiers, bishops, and sailors in the colonies between the $17^{\text {th }}$ and $19^{\text {th }}$ centuries, based on the earliest available number for each country.

${ }^{65}$ Nunn and Puga 2012. This is the percentage of the land surface area of each country that has fertile soil (defined as soil that is not subject to severe constraints for growing rainfed crops).

${ }^{66}$ King and Zeng 2001.

${ }^{67}$ Carter and Signorino 2010.

${ }^{68}$ Rogers 1993. 


\section{Ethnic Conflict in Post-colonial States}

\section{Ethnic Stratification and the Equilibrium of Inequality}

Figure 1 compares the colonial settler states, decolonized states, and other multiethnic countries in terms of both dimensions of ethnic stratification: the stability of group hierarchy and ethnic groups' social segmentation. The former is measured by the average frequencies of onegroup dominance and ethnic power shifts observed in the data between 1946 and $2009 ;{ }^{69}$ the latter by the observed mean levels of linguistic and religious segmentation. The results show sharp differences between the three state types. Ethnic group relations are clearly most hierarchical in the colonial settler states. One-group dominance is the common situation in these states, while ethnic power shifts are very rare. In contrast, although they are not spared from the risk of ethnic dominance, the decolonized states feature much more fluid ethnic power structures, as different ethnic groups become politically included and excluded over time. Specifically, the frequency of ethnic power shifts is much higher than in both the colonial settler states and other multiethnic countries.

Interestingly, the values of the countries that remained unaffected by European overseas colonialism lie exactly in between those of the European ex-colonies. While nation-state building has also resulted in ethnic inequalities in these states,${ }^{70}$ their group hierarchies are, on average, clearly less pronounced than in the colonial settler states. Overall, the two types of European excolonies constitute actual poles in terms of group hierarchization, testifying to the distinct longterm consequences of this particular instance of colonialism.

\footnotetext{
${ }^{69}$ Note that I multiplied the ethnic power shifts values by 10 to make them compatible with the scale of the other three variables displayed in Figure 1.

${ }^{70}$ See Hechter 1975; Mann 2005; Wimmer 2002.
} 
[Figure 1]

As previously argued, the decolonized states and the countries that remained unaffected by European overseas colonialism are much more similar in terms of ethnic groups' segmentation. In fact, the latter category even displays somewhat higher average values of linguistic and religious segmentation. Both of these state types differ hugely from the colonial settler states which exhibit by far the lowest segmentation values. In other words, ethnic groups in these states are not only very hierarchically organized, but also highly integrated in social terms. This provides strong evidence for the stratified nature of the colonial settler states.

Figure 2 illustrates how these distinct cleavage types affect the likelihood of ethnic civil conflict. It shows the observed rates of ethnic conflict onset in the colonial settler states, the decolonized states, and other multiethnic countries between 1946 and 2009, according to the two different operational definitions described above (ethnic claim and recruitment vs. either claim or recruitment). Ethnic stratification in the settler states goes hand in hand with a significantly lower risk of violent ethnic conflict. The average frequency of ethnic conflict onset was about eight times lower in the colonial settler states than in the decolonized states, and over four times lower than in other multiethnic countries. The results do not change very much when employing the broader operational definition of ethnic conflict. In fact, the difference between the two classes of post-colonial states becomes even starker.

[Figure 2] 
Modeling the risk of ethnic conflict onset in all multiethnic states between 1946 and 2009, the logit regression analyses in Table 2 provide further evidence for the theoretical argument, by controlling for the influence of other relevant factors. I first show a reference model composed of the most commonly used explanatory variables in quantitative civil war research. I then introduce two dummy variables for the decolonized states and other multiethnic countries, with the colonial settler states as the baseline category. The results of Model 1 mirror the findings in the existing literature. ${ }^{71}$ Low economic development, large populations, and the prior occurrence of ethnic violence all increase the risk of ethnic conflict. The results also confirm that a democratic state system by itself does not necessarily prevent the outbreak of inter-group violence. Introducing the two dummy variables, Model 2 reveals that the decolonized states and other multiethnic countries indeed have a significantly higher ethnic conflict risk, as expected, even when controlling for other factors, such as economic development and the level of democracy. The GDP per capita variable actually loses a considerable part of its effect once we introduce the state type dummies. All other variables behave more or less the same as in the reference Model 1.

[Table 2]

Model 3 again takes into account those instances of civil violence where rebel organizations relied heavily on specific ethnic groups without making explicit ethnic demands. Thus, the model replicates Model 2, using the alternative ethnic conflict onset variable, based on the

\footnotetext{
${ }^{71}$ See, e.g., Collier and Hoeffler 2004; Fearon and Laitin 2003; Hegre and Sambanis 2006.
} 
broader operational definition of ethnic conflict, as dependent variable. ${ }^{72}$ This leaves the results virtually unaffected. Even the residual category of other multiethnic countries still exhibits a clearly higher ethnic conflict risk than the settler states. Model 4 adds the controls for state age and ethnic homogeneity. The empirical results do not support the alternative explanations discussed above. Neither of these control variables exerts a statistically significant effect on the dependent variable. In contrast, the state type dummy variables remain robustly related to a higher probability of ethnic conflict onset.

Thus, the consolidation of state and nation by itself cannot account for the enormous difference in ethnic conflict risk between the colonial settler states and the decolonized states (and other multiethnic countries). Indeed, many highly homogenous countries among decolonized and titular nation states - for example, the Philippines, Azerbaijan, and Georgia - have experienced protracted ethnic conflicts between the state and small minorities. Extremely small ethnic groups (sometimes constituting less than one percent of their country's population) have also been able to mount serious military challenges to such countries as Russia, India, Myanmar, or Bangladesh. Thus, group size by itself can certainly not account for the lack of armed mobilization by small minorities in the colonial settler states.

Appendix 4 presents seven additional robustness models. ${ }^{73}$ Models A1 and A2 control for the identity of the colonizers by including dummy variables for the six most important colonial powers (measured by the number of observations in the dataset of this study). Model A1 only

\footnotetext{
${ }^{72}$ Note that the model also uses adjusted ethnic conflict history and peace years variables that are in line with the different version of the outcome variable.

${ }^{73}$ Note that due to missing observations in the additional control variables, the number of observations decreases in some of these robustness models.
} 
includes the alternative colonial classifiers, whereas Model A2 tests them against my own state type dummy variables. Model A3 includes the violent independence dummy variable, and Model A4 uses the indicator of states' taxing capacity as an alternative measure of state strength. Model A5 replaces the Polity index with the V-Dem indicator of participatory democracy to test whether the results are robust to the use of alternative measures of democracy. This index measures the degree of active participation by citizens in all political processes, both electoral and nonelectoral, and is therefore well-suited to gauge the relationship between democratic freedom and the choice of violent or non-violent contention. ${ }^{74}$ Furthermore, Model A6 controls for countries' natural resource profile proxied by their per capita oil and diamond production quantities. The two state type dummies remain completely robust in all models. In Model A1, the effect of the Spanish colony dummy is statistically significant. Yet, it is clearly weaker than the effects of the state type dummies and turns insignificant once the latter are included in Model A2. The other additional controls do not exert a statistically significant effect on the dependent variable. All remaining variables behave more or less the same as in Table 2 .

Finally, Model A7 tackles potential concerns of endogeneity in my main independent variables. The above analysis considered the colonial settler states and decolonized states (and other multiethnic countries) as state types that received a distinct treatment in terms of colonial heritage, entailing distinct ethnic cleavage types. However, these colonial legacies could themselves be the results of causally prior factors that were not only responsible for how colonialism ended but subsequently also influenced the likelihood of post-independence ethnic conflict. My empiri-

\footnotetext{
${ }^{74}$ I also ran Model A5 using the V-Dem indicators of electoral and liberal democracy. The results are virtually the same. I refrain from including these three indicators together in the same model because they are extremely highly correlated (pairwise correlations above $r=0.97$ ).
} 
cal approach in Model A7 is based on the idea that how colonialism ended depended on the timing and intensity of European settlement. ${ }^{75}$ Territories with earlier and higher influx of European settlers were more likely to become independent under European rule, i.e. as colonial settler states. In turn, this influx of settlers was likely to be influenced by the accessibility and attractiveness of the territories. Easily accessible territories that offered living conditions conducive to European settlers, as well as those that promised exploitable resources were more likely to experience early and extensive European settlement. Hence, Model A7 tests whether the consideration of the physical accessibility (distance to coast), historical disease environment (logged settler mortality rates), and historical resource richness (soil fertility) of countries undermines the explanatory weight of my main treatment. ${ }^{76}$

The results speak against the notion of endogeneity. While none of these additional control variables exerts a significant effect on ethnic conflict risk, the two state type dummy variables remain robustly related to the outcome variable. In summary, these results provide strong support for hypothesis $\mathrm{H} 1$ and highlight the long-term consequences of the ethnic cleavage types produced by distinct outcomes of European overseas colonial rule.

${ }^{75}$ See Acemoglu, Johnson, and Robinson 2001.

${ }^{76}$ Alternatively, I also ran Model A7 using a measure of the fraction of the population with European descent in 1900, also taken from Acemoglu, Johnson, and Robinson 2001, instead of these three variables. The main difference in the results is that the effect of the dummy variable for other multiethnic countries also becomes highly significant again. Note that the number of observations in this model decreases considerably because the data on settler mortality focus on ex-colonies broadly defined, see Acemoglu, Johnson, and Robinson 2001, 1370, 1377. Yet, they also include many countries that are considered non-colonized states in my classification, such as China, Thailand, and Ethiopia. Therefore, I keep both state type dummy variables in this model. 
Testing the Mechanisms: The Origins of the Equilibrium of Inequality

In order to get closer to the causal mechanisms driving these findings, the present section focuses on the two properties of ethnic cleavage types highlighted in the theoretical argument: between-group hierarchies and social integration. This also serves to test the main tenets of my theory for all multiethnic countries in general. Models 5 through 7 in Table 3 examine the explanatory power of these cleavage properties, by including three additional variables: the count variable of the consecutive years of one-group dominance as a measure of group hierarchization, as well as the linguistic and religious segmentation indicators. Model 5 tests their effects on ethnic conflict onset in general, whereas Models 6 and 7, respectively, focus on governmental and territorial conflicts only. All models control for the degree of ethnic groups' geographic overlap. They also include the continuous indicator of the relative size of all excluded groups to control for the impact of ethnic exclusion per se (independent of ethnic dominance), as analyzed in previous studies. ${ }^{77}$

[Table 3]

In Model 5, the coefficients of all three cleavage variables point in the expected directions and are statistically significant. First, the results give strong support to the effect of social segmentation, referred to in hypothesis $\mathrm{H} 3$, although in the case of religious segmentation the coefficient falls short of the standard $95 \%$ confidence level $(p=0.07)$. Generally, the more segmented

${ }^{77}$ See, e.g., Cederman, Gleditsch, and Buhaug 2013; Wimmer, Cederman, and Min 2009. 
ethnic groups are in either linguistic or religious terms, the more likely is ethnic conflict. Second, the results also highlight the importance of stable between-group hierarchies, as expressed in hypothesis $\mathrm{H} 2$. The longer political dominance lasts - i.e. the more stable group hierarchies are the lower the risk of ethnic conflict. At the same time, the ethnic exclusion indicator has a significant positive effect on ethnic conflict risk. Hence, while ethno-political inequality generally increases the risk of ethnic conflict onset, stable group hierarchies - in the form of long-term ethnic dominance - make ethnic conflict less likely. This attests to the relevance of the distinction between different regimes of ethnic exclusion.

Figure 3 shows a contour plot of the risk of ethnic civil conflict as a function of both linguistic segmentation and the number of consecutive years of one-group dominance, based on Model 5. It confirms that conflict risk is greatest where group hierarchies are least stable and ethnic groups are most segmented. This is the area in the bottom right corner. The figure also suggests that between the two variables, linguistic segmentation has a stronger effect on ethnic conflict risk. At high levels of segmentation, the risk of civil conflict is still higher even if the group hierarchy is very pronounced (area in the upper right corner) than at low hierarchization values combined with low linguistic segmentation (bottom left corner). This is precisely why the few highly hierarchical decolonized states (such as Sudan) are still more likely to experience violent ethnic conflict than the equally hierarchical, but much more integrated colonial settler states. It also explains the higher conflict rates of non-colonized but segmented nation states, such as Turkey, Thailand, or the ex-Soviet province of Azerbaijan, compared to the settler states.

[Figure 3] 
Models A8 and A9 in Appendix 5 show that these results are robust to alternative measures of ethnic heterogeneity. Model A8 controls for the number of relevant ethnic groups in a country (according to EPR-ETH), while Model A9 includes the ethnic fractionalization and polarization indices from Alesina et al. ${ }^{78}$ None of these control variables alters the results in any significant way. Finally, Model A10 tests for a potential non-linear effect of the years of one-group dominance by including a quadratic version of the variable. To interpret the coefficients and visualize the precise form of the effect of between-group hierarchies, Appendix 6 plots the predicted probabilities of ethnic conflict onset as a function of the number of dominance years, based on Model A10. It shows that there is only a relatively soft curve in the predicted probabilities. While the conflict risk slightly augments in the first years of ethnic dominance, it decreases steadily after about twenty years. This is very much in line with the theoretical argument of this study. The notion of stratification advanced therein implies very stable group hierarchies (besides high social integration) that go beyond the more temporary ebbs and flows of ethnic inclusion and exclusion. Hence, the negative effect of ethnic dominance persistence only becomes really pronounced after a large number of years, i.e. when between-group hierarchies are indeed highly entrenched.

Furthermore, Models 6 and 7 in Table 3 lend support to hypothesis H4, confirming the distinct effects of hierarchization and segmentation on governmental and territorial conflicts, respectively. ${ }^{79}$ The size of the coefficient of the hierarchization variable almost doubles in the governmental-conflict Model 6 compared to Model 5, but becomes considerably weaker and statisti-

\footnotetext{
${ }^{78}$ Alesina et al. 2003.

${ }^{79}$ Again, these two models use adjusted peace years variables that refer to the distinct outcome variables (i.e. to governmental and territorial conflicts, in particular).
} 
cally insignificant when it comes to territorial conflicts. In contrast, the effect of linguistic segmentation becomes much stronger and more significant in the territorial-conflict Model 7 compared to Model 5, whereas it is almost indistinguishable from 0 in Model 6. The effect of religious segmentation is consistently positive and somewhat more important for territorial than governmental conflicts, but remains statistically insignificant in these models. Overall, these findings lend strong credibility to my theory by showing that its main tenets are valid for multiethnic states in general.

\section{A Look Back in History}

The comparison between colonial settler states and decolonized states could be flawed if most ethnic rebellions in the former occurred soon after independence. In this case, the above analysis - setting in in 1946 - would simply miss the relevant time period in the colonial settler

states. To examine this possibility, I draw on the COW intrastate war dataset, ${ }^{80}$ the only conflict dataset that reaches back into the $19^{\text {th }}$ century, to compare the frequency of ethnic civil conflict in the first 70 years after independence of all European ex-colonies. Since the COW data do not distinguish between ethnic and non-ethnic conflicts, I manually classified all included conflict instances in this time period according to the same criteria of claim and recruitment applied in the post-World War II period. ${ }^{81}$

${ }^{80}$ Sarkees and Wayman 2010.

${ }^{81}$ Note that the COW dataset employs a much higher threshold of 1000 battle-related deaths per year than the UCDP/PRIO Armed Conflicts Dataset. The COW data also code civil war onsets for countries when 
Figure 4 shows the ethnic conflict rate (defined as the number of onsets divided by the number of country observations) in each of these first 70 years after independence in both categories of post-colonial states. The results clearly reveal that even immediately after independence, the colonial settler states experienced very few ethnic civil conflicts and much fewer than the decolonized states would experience after their independence a century later. There are only eight conflicts recorded in the COW data that can be coded as ethnically based $(0.4 \%$ of all country years), compared to 51 in the decolonized states $(1.4 \%$; two-tailed t-test: $p=0.000) .{ }^{82}$ Thus, the theorized equilibrium of inequality resulting from profound ethnic stratification has been a constant feature of the colonial settler states.

[Figure 4]

\section{Conclusion}

The findings of this article suggest that the present-day dynamics of ethnic politics continue to be profoundly shaped by the legacies of distinct colonial experiences. Indeed, one could argue that colonialism has never really ended in the settler states where the conquered groups continue to form the lower stratum of relatively integrated systems of ethno-classes. This internal

they are involved in civil wars of other countries (e.g., the US interventions in Somalia or Laos). I excluded these cases from my analysis.

${ }^{82}$ The ethnic civil conflicts that occurred in the colonial settler states during their first 70 years of independence include, for example, the black uprising in Cuba in 1912, the Caste War of Yucatán in Mexico, the conquest of Patagonia in Argentina, and the violent conflicts in Zimbabwe. 
colonialism is not only associated with high stratification but also with significantly lower levels of inter-group violence than in other multiethnic countries. In contrast, the later resource colonies that were liberated from colonial rule now grapple with societies divided into distinct ethnic segments whose boundaries and identities were very much institutionalized by European colonizers imbued with ethno-nationalist ideas and eager to divide the subjugated population. Although - or precisely because - ethnic hierarchies tend to be less pervasive in these states, ethnic group mobilization is more likely to turn violent than in the colonial settler states.

These findings deviate from the expectations inherent in many existing theories of ethnic conflict that civil violence should be most likely where inter-group inequalities are most profound. ${ }^{83}$ Instead, they show that historically determined ethnic stratification may result in an equilibrium of inequality, in which marginalized groups lack both the organizational strength and the opportunities for armed rebellion. Beyond the comparison of post-colonial states, the empirical results of this study suggest that ethnic conflict is most likely where the ethnic cleavages created by the historical processes of state building run vertically between socially segmented groups. Hence, while the colonial settler states are certainly not the only countries with durable regimes of ethnic dominance, the theorized equilibrium of inequality seems to be contingent on the degree to which oppressors and oppressed form "ascriptively defined components of a single society. $" 84$ It is most powerful in the colonial settler states because they constitute archetypical cases of such ranked ethnic systems.

However, it is important to bear in mind that this article has focused on a particular type of inter-group violence, namely civil war. Its findings do not necessarily apply equally to the rela-

${ }^{83}$ Cederman, Gleditsch, and Buhaug 2013; Stewart 2008; Wimmer 2002.

${ }^{84}$ Horowitz 1985, 23. 
tionship between ethnic mobilization and other forms of inter-group violence, such as communal violence. Also, particular strategies of violence, as, for example, terrorism, may exhibit distinct dynamics that escape the underlying premises of my theoretical argument. For instance, the organizational strength of group mobilization necessary to carry out terrorist attacks is likely to be lower than what is required for the formation of an armed group capable of fighting in a civil conflict (even a low-level conflict). Nevertheless, by using an operational definition of ethnic civil war with a relatively low threshold of battle deaths, the above analysis also captured many of these low-scale instances of inter-group violence.

What are the broader implications of these results for the academic research on ethnic politics? First of all, whereas conflict researchers often follow Barth's encompassing approach to ethnicity, which draws no distinction between different ethnic markers ${ }^{85}$ this article emphasizes the lasting political impact of distinct ethnic cleavage types related to specific markers, such as race, language, and religion. Specifically, in contrast to the stratifying force of race, linguistic and religious segmentation of ethnic groups increases the risk of violent ethnic conflict. Moreover, previous studies that focused on specific ethnic markers tended to regard religious divisions as particularly violence-prone. ${ }^{86}$ In contrast, the results of this study suggest that linguistic segmentation might actually be more critical than religious segmentation, especially for separatist violence. This structural approach to explaining ethnic groups' opportunities for secession also contributes to the literature on secessionist conflicts, which so far has mostly focused on groups'

\footnotetext{
${ }^{85}$ Barth 1969.

${ }^{86}$ E.g., Juergensmeyer 1993; Hassner 2009. An exception is Bormann, Cederman, and Vogt Forthcoming.
} 
grievances, ${ }^{87}$ trans-border ethnic kin relations, ${ }^{88}$ institutional opportunities for mobilization, ${ }^{89}$ and the strategic interaction between state governments and ethnic challengers. ${ }^{90}$

Second, the results of this study also suggest that rather than treating ethnic inequality and the political opportunity structure as two alternative explanations for civil war, we should regard both of these factors (as well as groups' mobilization capacity) as at least partly a function of distinct structures of ethnic group relations. By emphasizing the historical roots of these structures, the study joins a recent literature that has analyzed the lasting effects of specific colonial legacies. ${ }^{91}$ Yet, in contrast to these studies, which have usually examined the legacies of different colonial powers in terms of democratic political institutions and economic development, I argue that when it comes to ethno-political institutions and conflict, the crucial distinction lies in the ethno-racial identity of the promoters and beneficiaries of independence.

Finally, if we envision ethnic politics as playing out in a dyadic relationship between the government and its challengers,${ }^{92}$ my findings have implications for the understanding of either side. On the one hand, certain types of ethnic cleavages are more likely to feature what Tilly called "durable inequality"93 than other cleavage types, which are associated with less pervasive

\footnotetext{
${ }^{87}$ See, e.g., Gurr et al. 1993.

${ }^{88}$ Cederman et al. 2013; Saideman 1997.

${ }^{89}$ See, e.g., Brancati 2006.

${ }^{90}$ Walter 2006.

${ }^{91}$ Acemoglu and Robinson 2012; Bernhard, Reenock, and Nordstrom 2004; Lange, Mahoney, and vom Hau 2006; Mahoney 2010.

${ }^{92}$ Cederman, Wimmer, and Min 2010; Tilly 1978.

93 Tilly 1998.
} 
inter-group inequality. At the same time, higher equality often carries with it an element of competition. In such a situation, ethnic movements may play a highly dangerous role by fueling ethnic violence. In contrast, the historical oppression built into stratified ethnic systems is usually challenged by more peaceful attempts of political emancipation. Hence, by highlighting the contrasting effects of ethnic movements as a consequence of distinct historical legacies, this study helps to systematize the wealth of empirical research on ethnic politics, and as such to move towards a comprehensive theory of inequality, mobilization, and violence in multiethnic states. 


\section{References}

Acemoglu, Daron, Simon Johnson, and James Robinson. 2001. The Colonial Origins of Comparative Development: An Empirical Investigation. The American Economic Review 91 (5): 1369-1401.

Acemoglu, Daron, and James Robinson. 2012. Why Nations Fail: The Origins of Power, Prosperity and Poverty. New York: Crown.

Alesina, Alberto, Arnaud Devleeschauwer, William Easterly, Sergio Kurlat, and Romain Wacziarg. 2003. Fractionalization. Journal of Economic Growth 8 (2): 155-194.

Barth, Fredrik. 1969. Introduction. In Ethnic Groups and Boundaries: The Social Organization of Culture Difference, edited by Fredrik Barth, 9-38. Bergen: Universitetsforlaget.

Bernhard, Michael, Christopher Reenock, and Timothy Nordstrom. 2004. The Legacy of Western Overseas Colonialism on Democratic Survival. International Studies Quarterly 48 (1): $225-250$.

Blanton, Robert, T. David Mason, and Brian Athow. 2001. Colonial Style and Post-Colonial Ethnic Conflict in Africa. Journal of Peace Research 38 (4): 473-491.

Blaydes, Lisa, and Christopher Paik. 2016. The Impact of Holy Land Crusades on State Formation: War Mobilization, Trade Integration, and Political Development in Medieval Europe. International Organization 70 (03): 551-586.

Bormann, Nils-Christian, Lars-Erik Cederman, and Manuel Vogt. Forthcoming. Language, Religion, and Ethnic Civil War. Journal of Conflict Resolution.

Brancati, Dawn. 2006. Decentralization: Fueling the Fire or Dampening the Flames of Ethnic Conflict and Secessionism? International Organization 60 (03): 651-685. 
Carter, David B., and Curtis S. Signorino. 2010. Back to the Future: Modeling Time Dependence in Binary Data. Political Analysis 18 (3): 271-292.

Cederman, Lars-Erik, Kristian Skrede Gleditsch, and Halvard Buhaug. 2013. Inequality, Grievances and Civil War. New York: Cambridge Univerisity Press.

Cederman, Lars-Erik, Kristian Skrede Gleditsch, Idean Salehyan, and Julian Wucherpfennig. 2013. Transborder Ethnic Kin and Civil War. International Organization 67 (2): 389-410. Cederman, Lars-Erik, Andreas Wimmer, and Brian Min. 2010. Why Do Ethnic Groups Rebel? New Data and Analysis. World Politics 62 (1): 87-119.

Chandra, Kanchan. 2005. Ethnic Parties and Democratic Stability. Perspectives on Politics 3 (2): $235-252$

Collier, Paul. 2009. Wars, Guns, and Votes: Democracy in Dangerous Places. New York: Harper Perennial.

Collier, Paul, and Anke Hoeffler. 2004. Greed and Grievance in Civil War. Oxford Economic Papers 56 (4): 563-595.

Coppedge, Michael, Staffan I. Lindberg, Svend-Erik Skaaning, and Jan Teorell. 2015. Measuring High Level Democratic Principles Using the V-Dem Data. V-Dem Working Paper Series 2015:6. Available at https://www.v-dem.net/media/filer_public/61/64/6164b8a0-656c-48408ac0-ce9e4a7c2b2f/v-dem_working_paper_2015_6.pdf. Accessed October 18, 2016.

Denny, Elaine K., and Barbara F. Walter. 2014. Ethnicity and Civil War. Journal of Peace Research 51 (2): 199-212.

Diamond, Larry. 1988. Class, Ethnicity, and Democracy in Nigeria: The Failure of the First Republic. Syracuse: Syracuse University Press. 
Elkins, Caroline, and Susan Pedersen, eds. 2005. Settler Colonialism in the Twentieth Century. New York: Routledge.

Esteban, Joan, and Debraj Ray. 2008. On the Salience of Ethnic Conflict. American Economic Review 98 (5): 2185-2202.

Fearon, James D., and David D. Laitin. 2003. Ethnicity, Insurgency, and Civil War. The American Political Science Review 97 (1): 75-90.

Gamson, William A. 1975. The Strategy of Social Protest. Homewood, IL: Dorsey Press.

Gleditsch, Kristian Skrede, and Michael D. Ward. 1999. Interstate System Membership: A

Revised List of the Independent States since 1816. International Interactions 25 (4): 393413.

Gleditsch, Nils Petter, Peter Wallensteen, Mikael Eriksson, Margareta Sollenberg, and Håvard Strand. 2002. Armed Conflict 1946-2001: A New Dataset. Journal of Peace Research 39 (5): 615-637.

Grandin, Greg. 2000. The Blood of Guatemala. Durham: Duke University Press.

Guelke, Adrian. 2012. Politics in Deeply Divided Societies. Cambridge, UK: Polity Press.

Gurr, Ted Robert, Barbara Harff, Monty G. Marshall, and James R. Scarritt. 1993. Minorities at Risk: A Global View of Ethnopolitical Conflicts. Washington, D.C.: United States Institute of Peace Press.

Gurr, Ted Robert, Keith Jaggers, and Will H. Moore. 1989. Polity II Codebook. Boulder, CO: University of Colorado.

Hassner, Ron E. 2009. War on Sacred Grounds. Ithaca, NY: Cornell University Press. Hechter, Michael. 1975. Internal Colonialism: The Celtic Fringe in British National Development, 1536-1966. Berkeley: University of California Press. 
Hegre, Havard, and Nicholas Sambanis. 2006. Sensitivity Analysis of Empirical Results on Civil War Onset. Journal of Conflict Resolution 50 (4): 508-535.

Hensel, Paul R. 2014. ICOW Colonial History Data Set, version 1.0. Available at http://www.paulhensel.org/icowcol.html. Accessed May 4, 2016.

Heston, Alan, Robert Summers, and Bettina Aten. 2011. Penn World Table Version 7.0.

Philadelphia, PA: Center for International Comparisons of Production, Income and Prices at the University of Philadelphia. Available at http://www.rug.nl/ggdc/productivity/pwt/pwtreleases/pwt-7.0. Accessed May 4, 2016.

Horowitz, Donald L. 1985. Ethnic Groups in Conflict. Berkeley, CA: University of California Press.

Humphreys, Macartan. 2005. Natural Resources, Conflict, and Conflict Resolution: Uncovering the Mechanisms. Journal of Conflict Resolution 49 (4): 508-537.

Joshua Project. 2011. Unreached Peoples of the World. Available at http://www.joshuaproject.net/. Accessed December 4, 2014.

Juergensmeyer, Mark. 1993. The New Cold War? Religious Nationalism Confronts the Secular State. Berkeley, CA: University of California Press.

King, Gary, Michael Tomz, and Jason Wittenberg. 2000. Making the Most of Statistical Analyses: Improving Interpretation and Presentation. American Journal of Political Science 44 (2): 347-361.

King, Gary, and Langche Zeng. 2001. Logistic Regression in Rare Events Data. Political Analysis 9 (2): 137-163.

Laitin, David D. 2000. Language Conflict and Violence: The Straw that Strengthens the Camel's Back. European Journal of Sociology 41 (1): 97-137. 
Lange, Matthew, James Mahoney, and Matthias vom Hau. 2006. Colonialism and Development: A Comparative Analysis of Spanish and British Colonies. American Journal of Sociology 111 (5): 1412-1462.

Lewis, M. Paul, ed. 2009. Ethnologue: Languages of the World. Dallas, TX: SIL International. Madrid, Raúl. 2012. The Rise of Ethnic Politics in Latin America. New York, NY: Cambridge University Press.

Mahoney, James. 2010. Colonialism and Postcolonial Development: Spanish America in Comparative Perspective. New York: Cambridge University Press.

Mann, Michael. 2005. The Dark Side of Democracy: Explaining Ethnic Cleansing. New York: Cambridge University Press.

Marable, Manning. 2007. Race, Reform, and Rebellion: The Second Reconstruction and Beyond in Black America, 1945-2006 3rd ed. Jackson, MS: University Press of Mississippi.

Marx, Anthony W. 1998. Making Race and Nation: A Comparison of South Africa, the United States, and Brazil. Cambridge, UK: Cambridge University Press.

Mason, T. David. 2003. Structures of Ethnic Conflict: Revolution Versus Secession in Rwanda and Sri Lanka. Terrorism and Political Violence 15 (4): 83-113.

McAdam, Doug. 1982. Political Process and the Development of Black Insurgency, 1930-1970. Chicago: University of Chicago Press.

McCarthy, John D., and Mayer N. Zald. 1977. Resource Mobilization and Social Movements: A Partial Theory. American Journal of Sociology 82 (6): 1212-1241.

Nunn, Nathan, and Diego Puga. 2012. Ruggedness: The Blessing of Bad Geography in Africa. Review of Economics and Statistics 94 (1): 20-36. 
Posner, Daniel N. 2005. Institutions and Ethnic Politics in Africa. New York: Cambridge University Press.

Rabushka, Alvin, and Kenneth Shepsle. 1972. Politics in Plural Societies: A Theory in Democratic Instability. Columbus, OH: Charles E. Merrill.

Radcliffe-Brown, Alfred R. 1965. Structure and Function in Primitive Society 6th ed. London, UK: Cohen \& West.

Reilly, Benjamin. 2006. Political Engineering and Party Politics in Conflict-Prone Societies. Democratization 13 (5): 811-827.

Robinson, James. 2001. Social Identity, Inequality and Conflict. Economics of Governance 2 (1): 85-99.

Rogers, William H. 1993. Regression Standard Errors in Clustered Samples. Stata Technical Bulletin 3 (13): 88-94.

Saideman, Stephen M. 1997. Explaining the International Relations of Secessionist Conflicts: Vulnerability Versus Ethnic Ties. International Organization 51 (4): 721-753.

Sarkees, Meredith R., and Frank Wayman. 2010. Resort to War: 1816 - 2007. Washington DC: CQ Press.

Shelef, Nadav G. 2015. Unequal Ground: Homelands and Conflict. International Organization 70 (01): 33-63.

Smith, Michael G. 1969. Institutional and Political Conditions of Pluralism. In Pluralism in Africa, edited by Leo Kuper, and Michael G. Smith, 27-65. Berkeley, CA: University of California Press.

Stewart, Frances, ed. 2008. Horizontal Inequalities and Conflict: Understanding Group Violence in Multiethnic Societies. Houndmills: Palgrave Macmillan. 
Thies, Cameron G. 2010. Of Rulers, Rebels, and Revenue: State Capacity, Civil War Onset, and Primary Commodities. Journal of Peace Research 47 (3): 321-332.

Tilly, Charles. 1978. From Mobilization to Revolution. New York: McGraw-Hill.

---. 1998. Durable Inequality. Berkeley, CA: University of California Press.

Toft, Monica D. 2003. Indivisible Territory, Geographic Concentration, and Ethnic War. Princeton, NJ: Princeton University Press.

Vail, Leroy. 1989. Introduction: Ethnicity in Southern African History. In The Creation of Tribalism in Southern Africa, edited by Leroy Vail, 1-19. Berkeley, CA: University of California Press.

Vogt, Manuel. Forthcoming. Indigenous Movements and Ethnic Inclusion in Latin America. International Studies Quarterly.

Vreeland, James R. 2008. The Effect of Political Regime on Civil War: Unpacking Anocracy. Journal of Conflict Resolution 52 (3): 401-425.

Walter, Barbara F. 2006. Information, Uncertainty, and the Decision to Secede. International Organization 60 (1): 105-135.

Weber, Max. 1976[1922]. Wirtschaft und Gesellschaft: Grundriss der verstehenden Soziologie [Economy and Society: An Outline of Interpretive Sociology], 5th ed. Tübingen: J.C.B. Mohr.

Weidmann, Nils B. 2009. Geography as Motivation and Opportunity: Group Concentration and Ethnic Conflict. Journal of Conflict Resolution 53 (4): 526-543.

Wimmer, Andreas. 2002. Nationalist Exclusion and Ethnic Conflict: Shadows of Modernity. New York: Cambridge University Press. 
Wimmer, Andreas, Lars-Erik Cederman, and Brian Min. 2009. Ethnic Politics and Armed Conflict: A Configurational Analysis of a New Global Data Set. American Sociological Review 74: 316-337.

Wucherpfennig, Julian, Nils Metternich, Lars-Erik Cederman, and Kristian S. Gleditsch. 2012. Ethnicity, the State, and the Duration of Civil Wars. World Politics 64 (1): 79-115.

Wucherpfennig, Julian, Nils Weidmann, Luc Girardin, Lars-Erik Cederman, and Andreas Wimmer. 2011. Politically Relevant Ethnic Groups across Space and Time: Introducing the GeoEPR Dataset. Conflict Management and Peace Science 28 (5): 423-437.

Young, Crawford. 1994. The African Colonial State in Comparative Perspective. New Haven, CT: Yale University Press. 


\section{Appendix 1. Politically relevant ethnic groups by country (EPR-ETH, version 2.0)}

\begin{tabular}{|c|c|}
\hline Country & Ethnic groups \\
\hline Afghanistan & $\begin{array}{l}\text { Aimaq, Turkmen, Tajiks, Pamir Tajiks, Qizalbash, Pashtuns, Nuristanis, Uzbeks, Baloch, Pashai, Brahui, } \\
\text { Hazaras }\end{array}$ \\
\hline Albania & Greeks, Albanians, Macedonians \\
\hline Algeria & Berbers, Arabs \\
\hline Angola & Ovimbundu-Ovambo, Bakongo, Lunda-Chokwe, Mbundu-Mestico, Cabindan Mayombe \\
\hline Argentina & Argentinians, Indigenous peoples \\
\hline Armenia & Armenians, Russians, Kurds \\
\hline Australia & Whites, Aborigines, Asians \\
\hline Austria & Slovenes, Austrians \\
\hline Azerbaijan & Lezgins, Armenians, Azeri \\
\hline Bahrain & Sunni Arabs, Shi'a Arabs \\
\hline Bangladesh & Bengali Muslims, Tribal-Buddhists, Biharis (Urdu-Speaker), Bengali Hindus \\
\hline Belarus & Russians, Byelorussians, Poles \\
\hline Belgium & Walloon, Germans, Flemings \\
\hline Benin & $\begin{array}{l}\text { Southwestern (Adja), Southeastern (Yoruba/Nagot and Goun), South/Central (Fon), Northern (Bariba, } \\
\text { Gurmanché/Betamaribe etc.) }\end{array}$ \\
\hline Bhutan & Sharchops, Lhotsampa (Hindu Nepalese), Ngalops (Drupka), Bhutanese \\
\hline Bolivia & Aymara, Bolivians, Quechua, Guaraní and other eastern indigenous groups \\
\hline $\begin{array}{l}\text { Bosnia and Herze- } \\
\text { govina }\end{array}$ & Roma, Serbs, Croats, Bosniaks/Muslims \\
\hline Botswana & Tswana, Tswapong, Mbukushu, Yeyi, White, Birwa, Kalanga, Kgalagadi, Herero/Mbanderu, San \\
\hline Brazil & Whites, Afro-Brazilians, Indigenous peoples \\
\hline Bulgaria & Macedonians, Bulgarians, Turkish, Pomaks, Roma \\
\hline Burundi & Tutsi, Hutu \\
\hline Cambodia & Khmer, Cham and Malays, Khmer Loeu (incl. Kui), Thai-Lao, Vietnamese, Chinese \\
\hline Cameroon & $\begin{array}{l}\text { Beti (and related peoples), Fulani (and other northern Muslim peoples), Bassa/Duala, Bamileke, South- } \\
\text { western Anglophones (Bakweri etc.), Northwestern Anglophones (Grassfielders) }\end{array}$ \\
\hline Canada & English speakers, Aboriginal peoples, French speakers \\
\hline $\begin{array}{l}\text { Central African } \\
\text { Republic }\end{array}$ & $\begin{array}{l}\text { Sara, Goula, Riverine groups (Mbaka, Yakoma, Banziri etc.), Baya, Northern groups (Baya, Banda, Man- } \\
\text { djia, Sara, Goula), Mbaka, Yakoma }\end{array}$ \\
\hline Chad & Hadjeraï, Sara, Muslim Sahel groups, Toubou, Arabs, Zaghawa, Bideyat \\
\hline Chile & Chileans, Other indigenous peoples, Mapuche \\
\hline China & $\begin{array}{l}\text { Mulao, Hui, Oroqen, Evenk, Taiwanese, Dong, Gelo, Nu, Bonan, Xibe, Jingpo, Yi, Bouyei, Qiang, She, } \\
\text { Zhuang, Chinese (Han), Salar, Yugur, Daur, Blang, Koreans, Tujia, Manchu, Bai, Wa, Yao, Lisu, Uy- } \\
\text { ghur, Dai, Russians, Naxi, Maonan, Tajiks, Tu, Uzbeks, Tibetans, Pumi, Jinuo, Dongxiang, Jing, Achang, } \\
\text { Kirgiz, Lahu, Kazakhs, Mongolians, Shui, Miao, Hani, Li }\end{array}$ \\
\hline Colombia & Afrocolumbians, Columbians, Indigenous peoples \\
\hline Congo & $\begin{array}{l}\text { Niari peoples/region, Batéké, Kouyou, Lari/Bakongo, Nibolek (Bembe etc.), Lari, Vili, Mbochi, Mbochi } \\
\text { (proper), Bakongo }\end{array}$ \\
\hline
\end{tabular}




\begin{tabular}{|c|c|}
\hline Country & Ethnic groups \\
\hline Costa Rica & Indigenous peoples, Afro-Costa Ricans, Costa Ricans \\
\hline Croatia & Roma, Italians, Croats, Bosniaks, Hungarians, Serbs \\
\hline Cuba & Whites, Blacks \\
\hline Cyprus & Turks, Greeks \\
\hline Czechoslovakia & Hungarians, Roma, Slovaks, Czechs \\
\hline $\begin{array}{l}\text { Democratic Re- } \\
\text { public of the } \\
\text { Congo }\end{array}$ & $\begin{array}{l}\text { Ngbandi, Bakongo, Luba Kasai, Tetela-Kusu, Luba Shaba, Mongo, Mbandja, Azande-Mangbetu cluster, } \\
\text { Tutsi-Banyamulenge, Lulua, Other Kivu groups, Lunda-Yeke, Ngbaka }\end{array}$ \\
\hline Djibouti & Isaas (Somali), Afar \\
\hline Ecuador & Afroecuadorians, Ecuadorians, Indigenous peoples \\
\hline Egypt & Arab Muslims, Coptic Christians \\
\hline El Salvador & Salvadorans, Indigenous peoples \\
\hline Eritrea & Other Muslims, Other Muslims, Kunama, Christians, Afar \\
\hline Estonia & Ukrainians, Russians, Byelorussians, Estonians \\
\hline Ethiopia & $\begin{array}{l}\text { Somali (Ogaden), Muslim Eritreans, Amhara, Christian Eritreans, Oroma, Other Southern Nations, Hara- } \\
\text { ri, Afar, Beni-Shugal-Gumez, Tigry }\end{array}$ \\
\hline Fiji & Indians, Fijians \\
\hline Finland & Finns, Swedes \\
\hline France & French, Roma, Basques, Corsicans \\
\hline Gabon & Orungu, Fang, Nkomi, Myéné, Eshira/Bapounou, Mbédé (Batéké, Obamba) \\
\hline Gambia & Wolof, Fula, Diola, Aku (Creoles), Mandinka \\
\hline Georgia & Ossetians (South), Azeri, Russians, Armenians, Abkhazians, Georgians \\
\hline Ghana & Other Akans, Asante (Akan), Ga-Adangbe, Northern Groups (Mole-Dagbani, Gurma, Grusi), Ewe \\
\hline Greece & Muslims, Greeks, Macedonians, Roma \\
\hline Guatemala & Mayas, Guatemalans \\
\hline Guinea & Peul, Malinke, Susu \\
\hline Guinea-Bissau & Papel, Balanta, Manjaco, Cape Verdean \\
\hline Guyana & Indigenous peoples, Afro-Guyanese, Indo-Guyanese \\
\hline Honduras & $\begin{array}{l}\text { Hondurans, Indigenous peoples (Lenca, Maya-Chorti, Miskito, Tawahka/Sumu, Xicaque, Pech, Nahua), } \\
\text { Garifuna }\end{array}$ \\
\hline Hungary & Roma, Hungarians \\
\hline India & $\begin{array}{l}\text { Other Backward Classes (Castes), Indigenous Tripuri, Telugu (non-SC/ST), Bodo, Marathi (non-SC/ST), } \\
\text { Bengali (non-SC/ST), Tamil (non-SC/ST), Malyalam (non-SC/ST), Kannada (non-SC/ST/OBCs), Guja- } \\
\text { rati (non-SC/ST/OBCs), Scheduled Castes \& Tribes, Hindi (Non SC/ST/OBCs), Assamese (non-SC/ST), } \\
\text { Kashmiri Muslims, Other Muslims, Naga, Punjabi-Sikhs (non-SC/ST), Manipuri, Mizo, Oriya (non- } \\
\text { SC/ST/OBCs) }\end{array}$ \\
\hline Indonesia & $\begin{array}{l}\text { Ternate, Papua, Makassarese and Bugis, Malay, Achinese, Sundanese, Javanese, Madura, Amboinese, } \\
\text { Gorontalos, Minahasa, Minangkabaus, Chinese (Han), Balinese, Bataks, Dayak, East Timorese }\end{array}$ \\
\hline Iran & Zoroastrians, Bahais, Arabs, Kurds, Jews, Baloch, Persians, Azeri, Assyrians, Armenians, Turkmen \\
\hline Iraq & Kurds, Sunni Arabs, Shi'a Arabs \\
\hline Israel & Mizrahim (Jewish), Palestinian Arabs, Israeli Arabs, Ashkenazim (Jewish), Russians (Jewish) \\
\hline
\end{tabular}




\begin{tabular}{|c|c|}
\hline Country & Ethnic groups \\
\hline Italy & German speakers (Austrians), Friulians, Italians, Aostans (French speakers), Roma, Sardinians \\
\hline Ivory Coast & Southern Mande, Northerners (Mande and Voltaic/Gur), Baule, Other Akans, Kru \\
\hline Japan & Okinawans, Okinawans, Ainu, Koreans, Japanese \\
\hline Jordan & Palestinian Arabs, Jordanian Arabs \\
\hline Kazakhstan & Tatars, Kazakhs, Uighur, Russians, Uzbeks, Ukrainians, Germans \\
\hline Kenya & Kikuyu-Meru-Emb, Kalenjin-Masai-Turkana-Samburu, Mijikenda, Luo, Kisii, Luhya, Kamba, Somali \\
\hline Kosovo & Turks, Roma, Albanians, Serbs, Gorani \\
\hline Kuwait & Kuwaiti Shi'a (Arab), Bedoon, Kuwaiti Sunni (Arab) \\
\hline Kyrgyzstan & Kyrgyz, Uzbeks, Russians, Uyghur \\
\hline Laos & Lao Tai, Lao Thoeng (excl. Khmou), Lao Sung (excl. Hmong), Lao (incl. Phuan), Hmong, Khmou \\
\hline Latvia & Russians, Ukrainians, Latvians, Byelorussians \\
\hline Lebanon & $\begin{array}{l}\text { Greek Catholics, Armenian Orthodox, Protestants, Sunnis (Arab), Palestinians (Arab), Druze, Armenian } \\
\text { Catholics, Shi'a Muslims (Arab), Alawites, Maronite Christians, Greek Orthodox }\end{array}$ \\
\hline Liberia & Gio, Indigenous Peoples, Krahn (Guere), Americo-Liberians, Mano, Mandingo \\
\hline Libya & Arabs, Toubou \\
\hline Lithuania & Lithuanians, Russians, Poles \\
\hline Macedonia & Albanians, Serbs, Turks, Macedonians, Roma \\
\hline Madagascar & Highlanders, Côtiers \\
\hline Malawi & $\begin{array}{l}\text { Northerners (Tumbuka, Tonga, Ngonde), Southerners (Lomwe, Mang'anja, Nyanja, Yao), Chewa (Cen- } \\
\text { tral) }\end{array}$ \\
\hline Malaysia & East Indians, Dayaks, Chinese, Kadazans, Malays \\
\hline Mali & Arabs/Moors, Blacks (Mande, Peul, Voltaic etc.), Tuareg \\
\hline Mauritania & Sahrawis, Black Africans, Haratins (Black Moors), White Moors (Beydan) \\
\hline Mexico & Afromexicans, Mestizo, Indigenous peoples \\
\hline Moldova & Bulgarians, Gagauz, Russian speakers, Moldovans \\
\hline Mongolia & Kazakh, Mongols \\
\hline Montenegro & Croats, Serbs, Roma, Montenegrins, Bosniak/Muslims, Albanians \\
\hline Morocco & Sahrawis, Arabs, Berbers \\
\hline Mozambique & Makonde-Yao, Shona-Ndau, Tsonga-Chopi \\
\hline Myanmar & $\begin{array}{l}\text { Shan, Buddhist Arakanese, Kachins, Indians, Kayin (Karens), Indians, Bamar (Barman), Karenni (Red } \\
\text { Karens), Mons, Wa, Zomis (Chins), Chinese }\end{array}$ \\
\hline Namibia & $\begin{array}{l}\text { San, Nama, Basubia, Baster, Damara, Mafwe, Himba, Whites, Coloreds, Kavango, Herero, Mbanderu, } \\
\text { Ovambo }\end{array}$ \\
\hline Nepal & $\begin{array}{l}\text { Madhesi, Dalits both Hill \& Tarai, Muslims in the Terai, Rana/Thakuri, Tharus in the Terai, Hill Brah- } \\
\text { mins/Chetri, Adivasi/Janajati, Hill Brahmins/Chetri excl. Thakuri }\end{array}$ \\
\hline New Zealand & New Zealanders, Asians, Pacific Islanders, Maori \\
\hline Nicaragua & Afronicaraguans, Nicaraguans, Miskitos, Sumus \\
\hline Niger & Toubou, Kanouri, Djerma-Songhai, Hausa, Tuareg \\
\hline Nigeria & Tiv, Hausa-Fulani and Muslim Middle Belt, Ogoni, Yoruba, Ijaw, Igbo \\
\hline Pakistan & Bengali, Baluchis, Pashtuns, Mohajirs, Punjabi, Hindus, Sindhi, Ahmadis, Christians \\
\hline
\end{tabular}




\begin{tabular}{|c|c|}
\hline Country & Ethnic groups \\
\hline Panama & Ngobe-Bugle, Panamanians, Afropanamanians, Choco (Embera-Wounan), Kuna \\
\hline Paraguay & Paraguayans, Tupi-Guarani and other indigenous groups \\
\hline Peru & Aymara, Indigenous peoples of the Amazon, Peruvians, Quechua, Afroperuvians \\
\hline Philippines & Moro, Christian lowlanders, Fil-Chinese, Indigenous \\
\hline Poland & Roma, European and American Jews, Ukrainians, Byelorussians, Poles, Germans \\
\hline $\begin{array}{l}\text { Republic of Vi- } \\
\text { etnam }\end{array}$ & Kinh (Vietnamese), Hoa (Chinese) \\
\hline Romania & Germans, Hungarians, Roma, Romanians \\
\hline Russia & $\begin{array}{l}\text { Koreans, Georgians, Byelorussians, Tatars, Ukrainians, Buryats, Karelians, Abkhaz, Kalmyks, Turkmens, } \\
\text { Komi, Gagauz, Altai, Balkars, Khakass, Komi-Permyaks, Dargins, Jews, Tabasarans, Armenians, Ui- } \\
\text { ghurs, Bashkirs, Laks, Germans, Ingush, Tajiks, Poles, Chechens, Kazakhs, Moldovans, Karachai, Os- } \\
\text { setes, Armenians, Avars, Uzbeks, Latvians, Pamir Tajiks, Russians, Lezgins, Mordva, Finns, Udmurt, } \\
\text { Adyghe, Yakuts, Kabardins, Kirghis, Tuvinians, Lithuanians, Karakalpaks, Chukchi, Kumyks, Roma, } \\
\text { Crimean Tatars, Estonians, Nogai, Circassians, Mari, Azerbaijanis, Chuvashes }\end{array}$ \\
\hline Rwanda & Hutu, Tutsi \\
\hline Saudi Arabia & $\begin{array}{l}\text { Sunni Wahhabi (Najdi) (Arab), Ja'afari Shia (Eastern Province) (Arab), Sunni Shafii/Sofi (Hijazi) (Arab), } \\
\text { Ismaili Shia (South) (Arab) }\end{array}$ \\
\hline Senegal & Wolof, Mandingue (and other eastern groups), Serer, Pulaar (Peul, Toucouleur), Diola \\
\hline Sierra Leone & Limba, Kono, Temne, Mende, Creole, Northern Groups (Temne, Limba) \\
\hline Slovakia & Hungarians, Slovaks \\
\hline Slovenia & Italians, Serbs, Bosniaks, Hungarians, Albanians, Slovenes, Croats \\
\hline South Africa & $\begin{array}{l}\text { English Speakers, Pedi (North Sotho), Swazi, Tswana, Blacks, Zulu, Asians, Afrikaners, Coloreds, South } \\
\text { Sotho, Tsonga, Xhosa, San, Venda, Ndebele }\end{array}$ \\
\hline Spain & Catalans, Roma, Spanish, Basques, Galicians \\
\hline Sri Lanka & Moors (Muslims), Sinhalese, Sri Lankan Tamils, Indian Tamils \\
\hline Sudan & $\begin{array}{l}\text { Rashaida, Azande, Latoka, Dinka, Shilluk, Other Northern groups, Nuba, Beja, Bari, Nuer, Fur, Shaygiy- } \\
\text { ya, Ja'aliyyin and Danagla (Arab), Zaghawa, Other Southern groups, Masalit, Other Arab groups }\end{array}$ \\
\hline Switzerland & Swiss Italians, Swiss French, Swiss Germans \\
\hline Syria & Christians, Kurds, Alawi, Druze, Sunni Arabs \\
\hline Taiwan & Mainland Chinese, Taiwanese, Indigenous/Aboriginal Taiwanese \\
\hline Tajikistan & Russians, Uzbeks, Tajiks, Kyrgyz, Tatars \\
\hline Tanzania & Shirazi (Zanzibar Africans), Zanzibar Arabs, Mainland Africans, Maasai \\
\hline Thailand & Thai, Hill Tribes, Malay Muslims, Chinese, Shan \\
\hline Togo & Kabré (and related groups), Ewe (and related groups) \\
\hline $\begin{array}{l}\text { Trinidad and } \\
\text { Tobago }\end{array}$ & Blacks, East Indians \\
\hline Turkey & Roma, Turkish, Kurds \\
\hline Turkmenistan & Russians, Uzbeks, Kazakhs, Turkmen \\
\hline Uganda & $\begin{array}{l}\text { Langi/Acholi, South-Westeners (Ankole, Banyoro, Toro, Banyarwanda), Far North-West Nile (Kakwa- } \\
\text { Nubian, Madi, Lugbara, Alur), Teso, Kakwa-Nubian, Banyarwanda, Baganda, Karamojong, Far North- } \\
\text { West Nilers (Madi, Lugbara, Alur), Basoga, Northerners (Langi, Acholi, Teso), Asians, Northerners } \\
\text { (Langi, Acholi, Teso, Madi, Kakwa-Nubian, Lugbara, Alur), South-Westerners (Ankole, Banyoro, Toro), } \\
\text { Northerners (Langi, Acholi, Madi, Kakwa-Nubian, Lugbara, Alur) }\end{array}$ \\
\hline
\end{tabular}




\begin{tabular}{ll}
\hline Country & Ethnic groups \\
\hline Ukraine & Russians, Crimean Tatars, Romanians/Moldovans, Ukrainians, Hungarians \\
United Kingdom & Protestants In N. Ireland, Asians, Scots, English, Afro-Caribbeans, Catholics In N. Ireland, Welsh \\
$\begin{array}{l}\text { United States of } \\
\text { America }\end{array}$ & American Indians, Asian Americans, Arab Americans, Latinos, Whites, African Americans \\
Uruguay & Uruguayans, Afro-Uruguayans \\
Uzbekistan & Uzbeks, Russians, Tajiks, Karakalpak \\
Venezuela & Indigenous peoples, Venezuelans, Afrovenezuelans \\
Vietnam & Hoa (Chinese), Khmer, Thai, Tay, Kinh (Vietnamese), Nung, Muong, Hmong, Dao, Gia Rai \\
Yemen & Northerners, Southern Shafi'i, Northern Zaydis, Northern Shafi'i \\
Yemen Arab & Sunni Shafi'I (Arab), Zaydis \\
Republic & \\
Yugoslavia & Bosniaks/Muslims, Roma, Slovenes, Montenegrins, Serbs, Albanians, Hungarians, Croats, Macedonians \\
Zambia & $\begin{array}{l}\text { Nyanja speakers (Easterners), Lozi (Barotse), Kaonde, Tonga-Ila-Lenje, Lunda (NW Province), Bemba } \\
\text { speakers, Luvale (NW Province) }\end{array}$ \\
Zimbabwe & $\begin{array}{l}\text { Ndau (Shona sub-group), Africans, Manyika (Shona sub-group), Shona (minus Ndau), Ndebele-Kalanga- } \\
\text { (Tonga), Shona (minus Manyika \& Ndau), Europeans, Shona }\end{array}$ \\
\hline
\end{tabular}

Notes: The table lists all ethnic groups included in the EPR-ETH dataset, version 2.0, for each country. This list is time-variant.

For example, ethnic groups may split into different, politically relevant sub-groups or, reversely, lower-level ethnic categories may become politically relevant as parts of an overarching umbrella category. Therefore, the groups listed in the table for each country are not always politically relevant at the same time. 


\section{Appendix 2. Calculating linguistic and religious segmentation}

Linguistic and religious segmentation is calculated based on the EPR-ED dataset, ${ }^{94}$ which identifies the linguistic and religious identities of all ethnic groups included in the EPR-ETH dataset. Drawing on the Ethnologue ${ }^{95}$ and the Joshua Project, ${ }^{96}$ respectively, the EPR-ED dataset reports the three largest linguistic and religious identity fragments of each ethnic group in terms of their share of the total group population. Using the case of Romania as an example, Table A1 shows how the data are structured.

Table A1: The structure of the EPR-ED dataset

\begin{tabular}{|c|c|c|c|c|c|c|c|}
\hline Country & Group & Religion 1 & Religion 2 & Religion 3 & Language 1 & Language 2 & Language 3 \\
\hline Romania & Romanians & $\begin{array}{l}\text { Romanian } \\
\text { Orthodox }\end{array}$ & & & Romanian & & \\
\hline Romania & Hungarians & Protestantism & $\begin{array}{l}\text { Roman } \\
\text { Catholicism }\end{array}$ & & Hungarian & & \\
\hline Romania & Roma & $\begin{array}{l}\text { Romanian } \\
\text { Orthodox }\end{array}$ & & & $\begin{array}{l}\text { Romani- } \\
\text { Vlax }\end{array}$ & & \\
\hline Romania & Germans & $\begin{array}{l}\text { Roman Ca- } \\
\text { tholicism }\end{array}$ & Lutheranism & & German & & \\
\hline
\end{tabular}

The calculation was carried out as described below. Note that while the explanation here focuses on linguistic segmentation, the religious segmentation indicator was calculated in the exact same way.

${ }^{94}$ Bormann, Cederman, and Vogt Forthcoming.

${ }^{95}$ Lewis 2009.

${ }^{96}$ Joshua Project 2011. 
Step 1: The estimation process starts at the group level by comparing each ethnic group to all other groups in the same country in terms of the languages group members speak. Since each group can be composed of a maximum of three linguistic fragments, all fragments of each group are compared to all fragments of all other groups. If members of group A share at least one common language with members of group B, they receive a difference value of 0 . In contrast, if members of group A do not speak any of the up to three languages reported for group B in the dataset, the two groups are defined to be linguistically different, resulting in a difference value of 1.

Step 2: For each group, I sum up the linguistic difference values and divide this sum by the number of other ethnic groups in the country. This gives me a standardized average value of linguistic difference that indicates how much a given ethnic group differs from all other groups in the same country in terms of language. If the value is 1 , the group in question is linguistically different from all other groups. A value of 0 implies that the ethnic group shares a language with each other group in the country. If the average linguistic difference value equals 0.5 , this means that one of two other groups (or two of four other groups, etc.) in the country speaks the same language.

Step 3: The aggregated linguistic segmentation at the country level is simply defined as the mean value of all group values. Thus, the measure indicates from how many other groups in the country, on average, any ethnic group is linguistically distinct. For instance, a country-level value of 1 means that all groups in the country are linguistically distinct from all other groups. If a country has a between-group diversity value of 0.5 , this means that, on average, ethnic groups in that country are linguistically distinct from half of all other groups. 
Table A2 illustrates the construction of the linguistic and religious segmentation indicators, using the example of Romania from Table A1. The sum of linguistic differences is 3 for all four groups because each group differs from all three other groups in the country in terms of language. Dividing these sums by 3 (the number of other ethnic groups in the country) results in an average value of linguistic difference of 1 for all four groups. Hence, the country-level mean value of linguistic segmentation is also 1 . In terms of religion, both the Hungarians and the Germans contain one group fragment that practices Roman Catholicism, while the Romanians and the Roma are both overwhelmingly Romanian Orthodox. This means that each group shares one religious creed with one other group in the country, resulting in a sum of religious differences of 2 for all four groups. Dividing these sums by the number of other ethnic groups in the country leads to an average value of religious difference of 0.67 for all groups. Thus, the country-level mean value of religious segmentation also equals 0.67 .

Table A2: Estimation of the linguistic and religious segmentation indicators

\begin{tabular}{|c|c|c|c|c|c|c|c|}
\hline Group & Language & Sum of $\Delta$ & Avg. $\Delta$ & Religion 1 & Religion 2 & Sum of $\Delta$ & Avg. $\Delta$ \\
\hline Romanians & Romanian & 3 & 1 & $\begin{array}{l}\text { Romanian } \\
\text { Orthodox }\end{array}$ & & 2 & 0.67 \\
\hline Hungarians & Hungarian & 3 & 1 & Protestantism & $\begin{array}{l}\text { Roman Ca- } \\
\text { tholicism }\end{array}$ & 2 & 0.67 \\
\hline Roma & Romani-Vlax & 3 & 1 & $\begin{array}{l}\text { Romanian } \\
\text { Orthodox }\end{array}$ & & 2 & 0.67 \\
\hline Germans & German & 3 & 1 & $\begin{array}{l}\text { Roman Catholi- } \\
\text { cism }\end{array}$ & Lutheranism & 2 & 0.67 \\
\hline Country-level mean & & & 1 & & & & 0.67 \\
\hline
\end{tabular}




\section{Appendix 3. Summary statistics of the independent variables}

\begin{tabular}{|c|c|c|c|c|c|c|}
\hline Variable & $\mathbf{N}$ & Mean & Median & Std. Dev. & Min & Max \\
\hline $\begin{array}{l}\text { Ethnic dominance } \\
\text { dummy }\end{array}$ & 6,552 & .60 & 1 & .49 & 0 & 1 \\
\hline $\begin{array}{l}\text { Ethnic power shift } \\
\text { dummy }\end{array}$ & 6,419 & .05 & 0 & .23 & 0 & 1 \\
\hline $\begin{array}{l}\mathrm{N} \text { of consecutive } \\
\text { dominance years }\end{array}$ & 6,552 & 14.73 & 6 & 18.18 & 0 & 64 \\
\hline $\begin{array}{l}\text { Linguistic segmenta- } \\
\text { tion }\end{array}$ & 6,552 & .76 & .92 & .34 & 0 & 1 \\
\hline $\begin{array}{l}\text { Religious segmenta- } \\
\text { tion }\end{array}$ & 6,552 & .30 & .17 & .35 & 0 & 1 \\
\hline $\begin{array}{l}\text { Relative size of ex- } \\
\text { cluded groups }\end{array}$ & 6,552 & .23 & .12 & .26 & 0 & 1 \\
\hline Polity index & 6,458 & .04 & -1 & 7.32 & -10 & 10 \\
\hline $\begin{array}{l}\text { Population size (in } \\
\text { thousands) }\end{array}$ & 6,236 & $40,721.03$ & $9,936.63$ & $125,561.60$ & 163.79 & $1,323,59.00$ \\
\hline GDP per capita & 6,202 & $6,166.10$ & $3,011.85$ & $7,669.62$ & 49.97 & $43,69.90$ \\
\hline State age & 6,552 & 71.08 & 46 & 59.85 & 0 & 193.00 \\
\hline Largest group size & 6,552 & .63 & .63 & .23 & .16 & .98 \\
\hline $\begin{array}{l}\text { Ethnic conflict histo- } \\
\text { ry (strict definition) }\end{array}$ & 6,419 & .53 & 0 & 1.45 & 0 & 16 \\
\hline $\begin{array}{l}\text { Violent independence } \\
\text { dummy }\end{array}$ & 6552 & .51 & 1 & .50 & 0 & 1 \\
\hline Tax ratio & 3,683 & .15 & .13 & .09 & .002 & 1.19 \\
\hline $\begin{array}{l}\text { V-Dem participatory } \\
\text { democracy }\end{array}$ & 6451 & .25 & .16 & .21 & .00 & .83 \\
\hline $\begin{array}{l}\text { Per capita oil produc- } \\
\text { tion }\end{array}$ & 4,199 & .03 & .00 & .24 & 0 & 4.92 \\
\hline $\begin{array}{l}\text { Per capita diamond } \\
\text { production }\end{array}$ & 4,199 & .09 & 0 & .80 & 0 & 13.31 \\
\hline Distance from coast & 6480 & .39 & .28 & .40 & .00 & 2.21 \\
\hline Soil fertility & 6433 & 36.71 & 35.68 & 22.08 & 0 & 98.29 \\
\hline $\begin{array}{l}\text { Settler mortality } \\
\text { (logged) }\end{array}$ & 3856 & 4.57 & 4.36 & 1.35 & .94 & 7.99 \\
\hline $\begin{array}{l}\mathrm{N} \text { of dispersed ethnic } \\
\text { groups }\end{array}$ & 6,552 & .78 & 0 & 1.18 & 0 & 9 \\
\hline
\end{tabular}




\begin{tabular}{|c|c|c|c|c|c|c|}
\hline $\begin{array}{l}\mathrm{N} \text { of relevant ethnic } \\
\text { groups }\end{array}$ & 6552 & 5.14 & 4 & 6.75 & 1 & 57 \\
\hline $\begin{array}{l}\text { Ethnic fractionaliza- } \\
\text { tion }\end{array}$ & 6413 & .49 & .51 & .25 & .01 & .93 \\
\hline Ethnic polarization & 6413 & .59 & .64 & .21 & .02 & .97 \\
\hline Peace years & 6,552 & 19.61 & 15 & 17.52 & 0 & 63 \\
\hline
\end{tabular}




\section{Appendix 4. Robustness models: cleavage type and ethnic conflict onset}

\begin{tabular}{|c|c|c|c|c|c|c|c|}
\hline & Model A1 & Model A2 & Model A3 & Model A4 & Model A5 & Model A6 & Model A7 \\
\hline Decolonized states & & $\begin{array}{r}1.195^{* *} \\
(.381)\end{array}$ & $\begin{array}{r}1.337 * * * \\
(.385)\end{array}$ & $\begin{array}{r}1.031^{*} \\
(.427)\end{array}$ & $\begin{array}{r}1.180^{* *} \\
(.411)\end{array}$ & $\begin{array}{l}.989 * \\
(.421)\end{array}$ & $\begin{array}{r}1.440 * * \\
(.536)\end{array}$ \\
\hline $\begin{array}{l}\text { Other multiethnic } \\
\text { countries }\end{array}$ & & $\begin{array}{l}.781^{+} \\
(.427)\end{array}$ & $\begin{array}{r}1.109 * * \\
(.389)\end{array}$ & $\begin{array}{r}1.054^{*} \\
(.434)\end{array}$ & $\begin{array}{l}.833^{*} \\
(.417)\end{array}$ & $\begin{array}{l}.957^{*} \\
(.429)\end{array}$ & $\begin{array}{r}1.127^{+} \\
(.643)\end{array}$ \\
\hline British colony & $\begin{array}{r}-.092 \\
(.224)\end{array}$ & $\begin{array}{r}-.261 \\
(.239)\end{array}$ & & & & & \\
\hline French colony & $\begin{array}{r}.078 \\
(.255)\end{array}$ & $\begin{array}{l}-.250 \\
(.294)\end{array}$ & & & & & \\
\hline Spanish colony & $\begin{array}{r}-.985 * * \\
(.378)\end{array}$ & $\begin{array}{r}-.471 \\
(.314)\end{array}$ & & & & & \\
\hline Portuguese colony & $\begin{array}{r}.562 \\
(.734)\end{array}$ & $\begin{array}{r}.371 \\
(.722)\end{array}$ & & & & & \\
\hline Russian colony & $\begin{array}{r}-.052 \\
(.628)\end{array}$ & $\begin{array}{r}-.021 \\
(.642)\end{array}$ & & & & & \\
\hline $\begin{array}{l}\text { Turkish (Ottoman) } \\
\text { colony }\end{array}$ & $\begin{array}{r}-.494 \\
(.600)\end{array}$ & $\begin{array}{l}-.436 \\
(.616)\end{array}$ & & & & & \\
\hline Polity index (lagged) & $\begin{array}{r}.002 \\
(.018)\end{array}$ & $\begin{array}{r}.004 \\
(.017)\end{array}$ & $\begin{array}{l}.001 \\
(.016)\end{array}$ & $\begin{array}{r}.005 \\
(.021)\end{array}$ & & $\begin{array}{r}.014 \\
(.019)\end{array}$ & $\begin{array}{r}.024 \\
(.022)\end{array}$ \\
\hline $\begin{array}{l}\text { Population size } \\
\text { (logged) }\end{array}$ & $\begin{array}{l}.180^{*} \\
(.072)\end{array}$ & $\begin{array}{l}.176^{*} \\
(.068)\end{array}$ & $\begin{array}{r}.195 * * \\
(.063)\end{array}$ & $\begin{array}{l}.194 * \\
(.098)\end{array}$ & $\begin{array}{r}.198 * * \\
(.073)\end{array}$ & $\begin{array}{l}.182 * \\
(.087)\end{array}$ & $\begin{array}{l}.178^{*} \\
(.085)\end{array}$ \\
\hline $\begin{array}{l}\text { GDP per capita } \\
\text { (lagged, logged) }\end{array}$ & $\begin{array}{r}-.235^{*} \\
(.104)\end{array}$ & $\begin{array}{l}-.196 \\
(.110)\end{array}$ & $\begin{array}{l}-.179^{+} \\
(.113)\end{array}$ & $\begin{array}{l}-.157 \\
(.171)\end{array}$ & $\begin{array}{l}-.136 \\
(.114)\end{array}$ & $\begin{array}{r}-.225 \\
(.166)\end{array}$ & $\begin{array}{r}-.448^{* *} \\
(.164)\end{array}$ \\
\hline $\begin{array}{l}\text { Ethnic conflict histo- } \\
\text { ry }\end{array}$ & $\begin{array}{r}.232 * * * \\
(.043)\end{array}$ & $\begin{array}{r}.223 * * * * \\
(.045)\end{array}$ & $\begin{array}{r}.222 * * * * \\
(.042)\end{array}$ & $\begin{array}{r}.281 * * * \\
(.040)\end{array}$ & $\begin{array}{r}.233 * * * \\
(.037)\end{array}$ & $\begin{array}{r}.291 * * * \\
(.041)\end{array}$ & $\begin{array}{r}.224 * * * \\
(.045)\end{array}$ \\
\hline Peace years & $\begin{array}{l}-.080^{+} \\
(.047)\end{array}$ & $\begin{array}{l}-.066 \\
(.048)\end{array}$ & $\begin{array}{r}-.066 \\
(.047)\end{array}$ & $\begin{array}{r}-.020 \\
(.065)\end{array}$ & $\begin{array}{r}-.067 \\
(.046)\end{array}$ & $\begin{array}{l}-.048 \\
(.065)\end{array}$ & $\begin{array}{r}-.033 \\
(.061)\end{array}$ \\
\hline $\begin{array}{l}\text { Peace years (quadrat- } \\
\text { ic) }\end{array}$ & $\begin{array}{r}.003 \\
(.002)\end{array}$ & $\begin{array}{r}.003 \\
(.002)\end{array}$ & $\begin{array}{r}.003 \\
(.002)\end{array}$ & $\begin{array}{r}.001 \\
(.004)\end{array}$ & $\begin{array}{r}.003 \\
(.002)\end{array}$ & $\begin{array}{r}.002 \\
(.003)\end{array}$ & $\begin{array}{r}.002 \\
(.003)\end{array}$ \\
\hline Peace years (cubic) & $\begin{array}{l}-.000 \\
(.000)\end{array}$ & $\begin{array}{l}-.000 \\
(.000)\end{array}$ & $\begin{array}{r}-.000 \\
(.000)\end{array}$ & $\begin{array}{l}-.000 \\
(.000)\end{array}$ & $\begin{array}{r}-.000 \\
(.000)\end{array}$ & $\begin{array}{r}-.000 \\
(.000)\end{array}$ & $\begin{array}{l}-.000 \\
(.000)\end{array}$ \\
\hline $\begin{array}{l}\text { Violent independence } \\
\text { dummy }\end{array}$ & & & $\begin{array}{r}-.112 \\
(.210)\end{array}$ & & & & \\
\hline Tax ratio & & & & $\begin{array}{r}-1.149 \\
(1.668)\end{array}$ & & & \\
\hline $\begin{array}{l}\text { V-Dem participatory } \\
\text { democracy }\end{array}$ & & & & & $\begin{array}{l}-.965 \\
(.745)\end{array}$ & & \\
\hline $\begin{array}{l}\text { Per capita oil produc- } \\
\text { tion }\end{array}$ & & & & & & $\begin{array}{r}1.943 \\
(1.274)\end{array}$ & \\
\hline
\end{tabular}


Per capita diamond

production

Distance from coast

Soil fertility

Settler mortality

(logged)

Constant

Log likelihood

$$
\begin{array}{r}
-3.374 * * \\
(1.060)
\end{array}
$$
$-404.109 * * *$

Note: Robust standard errors, with clustering on countries, in parentheses. Log-likelihood figures obtained from standard logistic regressions. $* p<0.05, * * p<0.01, * * * p<0.001 .^{+} p \leq 0.1$ 
Appendix 5. Robustness models: between-group hierarchies, segmentation, and ethnic conflict onset

\begin{tabular}{|c|c|c|c|}
\hline & Model A8 & Model A9 & Model A10 \\
\hline $\mathrm{N}$ of consecutive dominance years & $\begin{array}{r}-.013^{*} \\
(.006)\end{array}$ & $\begin{array}{r}-.012 * \\
(.005)\end{array}$ & $\begin{array}{r}.028 \\
(.020)\end{array}$ \\
\hline $\begin{array}{l}\mathrm{N} \text { of consecutive dominance years } \\
\text { (quadratic) }\end{array}$ & & & $\begin{array}{r}-.001 * \\
(.000)\end{array}$ \\
\hline Linguistic segmentation & $\begin{array}{r}1.428 * * \\
(.521)\end{array}$ & $\begin{array}{r}1.629 * * \\
(.535)\end{array}$ & $\begin{array}{r}1.513 * * \\
(.515)\end{array}$ \\
\hline Religious segmentation & $\begin{array}{l}.619^{+} \\
(.358)\end{array}$ & $\begin{array}{l}.661^{+} \\
(.338)\end{array}$ & $\begin{array}{l}.619 * \\
(.311)\end{array}$ \\
\hline Relative size of excluded groups & $\begin{array}{r}1.185 * * * \\
(.359)\end{array}$ & $\begin{array}{r}1.145^{* *} \\
(.375)\end{array}$ & $\begin{array}{r}1.025 * * \\
(.355)\end{array}$ \\
\hline Polity index (lagged) & $\begin{array}{r}.015 \\
(.018)\end{array}$ & $\begin{array}{r}.012 \\
(.018)\end{array}$ & $\begin{array}{r}.022 \\
(.015)\end{array}$ \\
\hline Population size (logged) & $\begin{array}{r}.232 * * \\
(.090)\end{array}$ & $\begin{array}{r}.270 * * * \\
(.073)\end{array}$ & $\begin{array}{r}.236 * * * \\
(.066)\end{array}$ \\
\hline GDP per capita (lagged, logged) & $\begin{array}{r}-.137 \\
(.110)\end{array}$ & $\begin{array}{r}-.099 \\
(.114)\end{array}$ & $\begin{array}{r}-.122 \\
(.103)\end{array}$ \\
\hline Ethnic conflict history & $\begin{array}{r}.233 * * * \\
(.050)\end{array}$ & $\begin{array}{r}.212 * * * \\
(.056)\end{array}$ & $\begin{array}{r}.235 * * * \\
(.042)\end{array}$ \\
\hline State age & $\begin{array}{r}-.002 \\
(.002)\end{array}$ & $\begin{array}{r}-.002 \\
(.001)\end{array}$ & $\begin{array}{r}-.001 \\
(.002)\end{array}$ \\
\hline $\mathrm{N}$ of relevant ethnic groups & $\begin{array}{r}.002 \\
(.010)\end{array}$ & & \\
\hline Ethnic fractionalization & & $\begin{array}{r}.241 \\
(.445)\end{array}$ & \\
\hline Ethnic polarization & & $\begin{array}{c}.880^{+} \\
(.479)\end{array}$ & \\
\hline Largest group size & & & $\begin{array}{l}-.396 \\
(.494)\end{array}$ \\
\hline Number of dispersed ethnic groups & $\begin{array}{r}-.025 \\
(.067)\end{array}$ & $\begin{array}{r}-.014 \\
(.072)\end{array}$ & $\begin{array}{r}-.023 \\
(.080)\end{array}$ \\
\hline Peace years & $\begin{array}{r}-.055 \\
(.048)\end{array}$ & $\begin{array}{r}-.047 \\
(.048)\end{array}$ & $\begin{array}{r}-.054 \\
(.040)\end{array}$ \\
\hline Peace years (quadratic) & $\begin{array}{r}.003 \\
(.002)\end{array}$ & $\begin{array}{r}.002 \\
(.002)\end{array}$ & $\begin{array}{r}.002 \\
(.002)\end{array}$ \\
\hline Peace years (cubic) & $\begin{array}{r}-.000 \\
(.000)\end{array}$ & $\begin{array}{r}-.000 \\
(.000)\end{array}$ & $\begin{array}{r}-.000 \\
(.000)\end{array}$ \\
\hline Constant & $-6.400 * * *$ & $-7.913 * * *$ & $-6.502 * * *$ \\
\hline
\end{tabular}




\begin{tabular}{lrrr} 
& $(1.472)$ & $(1.468)$ & $(1.190)$ \\
$\mathrm{N}$ & & & 5,998 \\
Log likelihood & $-565.897 * * *$ & $-553.254 * * *$ & $-563.563 * * *$ \\
\hline
\end{tabular}

Note: Robust standard errors, with clustering on countries, in parentheses. Log-likelihood figures obtained from standard logistic regressions. $* p<0.05, * * p<0.01, * * * p<0.001{ }^{+} p \leq 0.1$ 


\section{Appendix 6. Effect of number of dominance years on ethnic conflict risk}

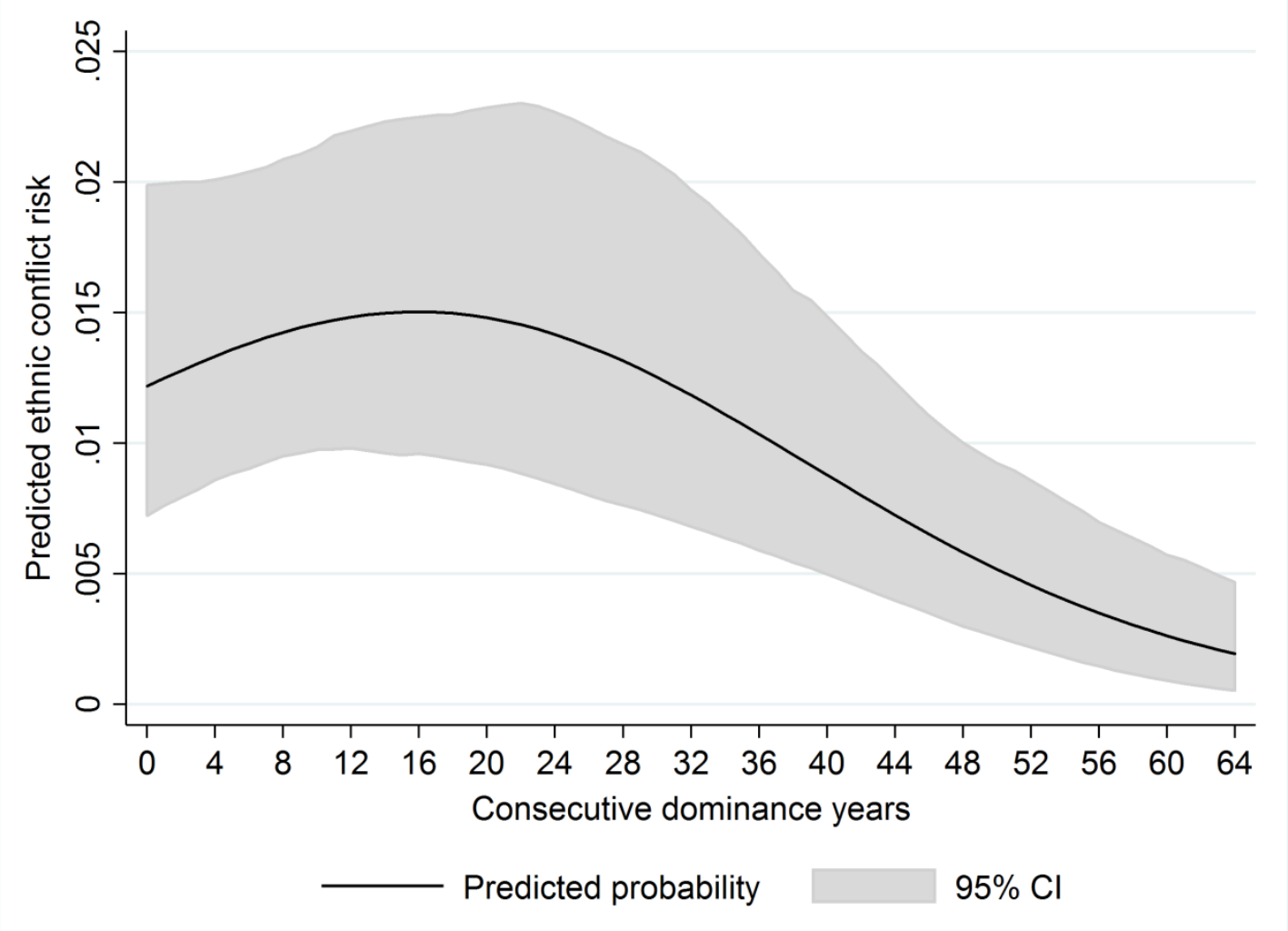

Notes: Based on Model A10 in Appendix 5 and calculated with simulation methods using Clarify; see King, Tomz, and Wittenberg 2000. Predicted probabilities of ethnic conflict onset as a function of the number of dominance years. All other variables held constant at their mean or median. 
Table 1: Classification of multiethnic states

\begin{tabular}{|c|c|c|c|c|}
\hline \multicolumn{3}{|c|}{ European overseas colonialism } & \multicolumn{2}{|c|}{ Other states } \\
\hline \multirow{3}{*}{$\begin{array}{l}\text { Colonial settler states } \\
\text { Argentina } \\
\text { Australia }\end{array}$} & \multicolumn{2}{|c|}{ Decolonized states } & \multirow{2}{*}{$\begin{array}{l}\text { Independent from } \\
\text { other foreign rule }\end{array}$} & \multirow{2}{*}{$\begin{array}{l}\text { Non-colonized } \\
\text { states }\end{array}$} \\
\hline & Algeria & Kenya & & \\
\hline & Angola & Kuwait & Albania & Ethiopia \\
\hline Bolivia & Bahrain & Laos & Armenia & France \\
\hline Brazil & Bangladesh & Lebanon & Austria** & Iran \\
\hline Canada & Benin & Libya & Azerbaijan & Italy \\
\hline Chile & Botswana & Madagascar & Belarus & Japan \\
\hline Colombia & Burundi & Malawi & Belgium & Liberia \\
\hline Costa Rica & Cambodia & Malaysia & Bhutan & Nepal \\
\hline Cuba & Cameroon & Mali & $\begin{array}{l}\text { Bosnia and Her- } \\
\text { zegovina }\end{array}$ & Russia \\
\hline Ecuador & $\begin{array}{l}\text { Central Afri- } \\
\text { can Republic }\end{array}$ & Mauritania & Bulgaria & Saudi Arabia \\
\hline El Salvador & Chad & Morocco & Croatia & Spain \\
\hline Guatemala & Congo & Mozambique & Czechoslovakia & Switzerland \\
\hline Honduras & Cyprus & Myanmar & Estonia & Thailand \\
\hline Mexico & $\begin{array}{l}\text { Dem. Rep. of } \\
\text { the Congo }\end{array}$ & Namibia & Finland & Turkey \\
\hline New Zealand & Djibouti & Niger & Georgia & United Kingdom \\
\hline Nicaragua & Egypt & Nigeria & Greece & \\
\hline Panama & Eritrea & Pakistan & Hungary & \\
\hline Paraguay & Fiji & Philippines & Kazakhstan & \\
\hline Peru & Gabon & Rwanda & Kosovo & \\
\hline South Africa & Gambia & Senegal & Kyrgyzstan & \\
\hline United States of America & Ghana & Sierra Leone & Latvia & \\
\hline Uruguay & Guinea & Sri Lanka & Lithuania & \\
\hline Venezuela & $\begin{array}{l}\text { Guinea- } \\
\text { Bissau }\end{array}$ & Sudan & Macedonia & \\
\hline \multirow[t]{13}{*}{ Zimbabwe } & Guyana & Syria & Moldova & \\
\hline & India & Tanzania & Mongolia & \\
\hline & Indonesia & Togo & Montenegro & \\
\hline & Iraq & $\begin{array}{l}\text { Trinidad and } \\
\text { Tobago }\end{array}$ & Poland & \\
\hline & Israel* & Uganda & Romania & \\
\hline & Ivory Coast & Vietnam & Slovakia & \\
\hline & Jordan & Zambia & Slovenia & \\
\hline & & & Taiwan & \\
\hline & & & Tajikistan & \\
\hline & & & Turkmenistan & \\
\hline & & & Ukraine & \\
\hline & & & Uzbekistan & \\
\hline & & & $\begin{array}{l}\text { Yemen / Yemen } \\
\text { Arab Republic } \\
\text { Yugoslavia/Serbia }\end{array}$ & \\
\hline
\end{tabular}


Notes: The table includes all countries, in which ethnicity has been politically relevant, according to the EPR-ETH dataset used in this study. Countries excluded due to this criterion are Burkina Faso, the Czech Republic, Denmark, the Dominican Republic, East Timor, Germany, Haiti, Ireland, Jamaica, Lesotho, the Netherlands, North Korea, Norway, Oman, Papua New Guinea, Portugal, Somalia, South Korea, Swaziland, Sweden, Tunisia, and the United Arab Emirates.

* Israel is also often treated as a settler state in the pertinent literature see, e.g., Elkins and Pedersen 2005. Yet, the Jewish settlement in Palestine was not connected to the colonial expansion of a European state. In contrast, the Jewish and Arab groups living in the territory of the present Israeli state became independent of Great Britain. Hence, I follow Hensel 2014 in considering Israel a former British colony (and therefore a decolonized state). Note, however, that the empirical results are very similar if Israel is included in the settler states category.

** Following Hensel 2014, the classification of Austria is based on its integration into Germany's "Third Reich." 
Table 2: Cleavage type and ethnic conflict onset. Rare-events logistic regression results

\begin{tabular}{|c|c|c|c|c|}
\hline & Model 1 & Model 2 & Model 3 & Model 4 \\
\hline Decolonized states & & $\begin{array}{r}1.379 * * * \\
(.380)\end{array}$ & $\begin{array}{r}1.418 * * * \\
(.317)\end{array}$ & $\begin{array}{r}1.356^{*} \\
(.532)\end{array}$ \\
\hline $\begin{array}{l}\text { Other multiethnic coun- } \\
\text { tries }\end{array}$ & & $\begin{array}{r}1.099 * * \\
(.388)\end{array}$ & $\begin{array}{r}1.053 * * * \\
(.319)\end{array}$ & $\begin{array}{r}1.080 * * \\
(.393)\end{array}$ \\
\hline Polity index (lagged) & $\begin{array}{r}-.001 \\
(.017)\end{array}$ & $\begin{array}{r}.003 \\
(.016)\end{array}$ & $\begin{array}{r}.008 \\
(.013)\end{array}$ & $\begin{array}{r}.002 \\
(.016)\end{array}$ \\
\hline Population size (logged) & $\begin{array}{r}.193 * * \\
(.070)\end{array}$ & $\begin{array}{r}.189 * * \\
(.065)\end{array}$ & $\begin{array}{l}.130 * \\
(.054)\end{array}$ & $\begin{array}{r}.178^{* *} \\
(.062)\end{array}$ \\
\hline $\begin{array}{l}\text { GDP per capita (lagged, } \\
\text { logged) }\end{array}$ & $\begin{array}{r}-.254 * \\
(.108)\end{array}$ & $\begin{array}{l}-.184^{+} \\
(.111)\end{array}$ & $\begin{array}{r}-.185^{+} \\
(.105)\end{array}$ & $\begin{array}{l}-.163 \\
(.110)\end{array}$ \\
\hline Ethnic conflict history & $\begin{array}{r}.237 * * * \\
(.041)\end{array}$ & $\begin{array}{r}.224 * * * \\
(.043)\end{array}$ & $\begin{array}{r}.175 * * * \\
(.032)\end{array}$ & $\begin{array}{r}.218 * * * \\
(.048)\end{array}$ \\
\hline Peace years & $\begin{array}{l}-.080^{+} \\
(.047)\end{array}$ & $\begin{array}{r}-.066 \\
(.047)\end{array}$ & $\begin{array}{r}-.161 * * * \\
(.044)\end{array}$ & $\begin{array}{r}-.062 \\
(.048)\end{array}$ \\
\hline Peace years (quadratic) & $\begin{array}{r}.003 \\
(.002)\end{array}$ & $\begin{array}{r}.003 \\
(.002)\end{array}$ & $\begin{array}{r}.007 * * \\
(.002)\end{array}$ & $\begin{array}{r}.003 \\
(.002)\end{array}$ \\
\hline Peace years (cubic) & $\begin{array}{r}-.000 \\
(.000)\end{array}$ & $\begin{array}{r}-.000 \\
(.000)\end{array}$ & $\begin{array}{r}-.000^{*} \\
(.000)\end{array}$ & $\begin{array}{r}-.000 \\
(.000)\end{array}$ \\
\hline State age & & & & $\begin{array}{r}.001 \\
(.003)\end{array}$ \\
\hline Largest group size & & & & $\begin{array}{r}-.607 \\
(.459)\end{array}$ \\
\hline Constant & $\begin{array}{r}-3.475 * * \\
(1.081)\end{array}$ & $\begin{array}{r}-5.168 * * * \\
(1.230)\end{array}$ & $\begin{array}{r}-4.134 * * * \\
(.999)\end{array}$ & $\begin{array}{r}-4.908 * * * \\
(1.191)\end{array}$ \\
\hline $\begin{array}{l}\mathrm{N} \\
\text { Log likelihood }\end{array}$ & $\begin{array}{r}5,998 \\
-579.913 * * *\end{array}$ & $\begin{array}{r}5,998 \\
-573.152 * * *\end{array}$ & $\begin{array}{r}5,998 \\
-668.165^{* * * *}\end{array}$ & $\begin{array}{r}5,998 \\
-572.031 * * *\end{array}$ \\
\hline
\end{tabular}

Note: Robust standard errors, with clustering on countries, in parentheses. Log-likelihood figures obtained from standard logistic regressions. $* p<0.05, * * p<0.01, * * * p<0.001 .^{+} p \leq 0.1$ 
Table 3: Between-group hierarchies, segmentation, and ethnic conflict onset. Rare-events logistic regression results

\begin{tabular}{|c|c|c|c|}
\hline & $\begin{array}{c}\text { Model } 5 \\
\text { All ethnic conflicts }\end{array}$ & $\begin{array}{c}\text { Model 6 } \\
\text { Governmental }\end{array}$ & $\begin{array}{c}\text { Model } 7 \\
\text { Territorial } \\
\end{array}$ \\
\hline $\mathrm{N}$ of consecutive dominance years & $\begin{array}{r}-.013^{*} \\
(.006)\end{array}$ & $\begin{array}{r}-.025^{*} \\
(.011)\end{array}$ & $\begin{array}{r}-.008 \\
(.006)\end{array}$ \\
\hline Linguistic segmentation & $\begin{array}{r}1.442 * * \\
(.508)\end{array}$ & $\begin{array}{r}-.090 \\
(.678)\end{array}$ & $\begin{array}{r}2.565 * * * \\
(.665)\end{array}$ \\
\hline Religious segmentation & $\begin{array}{c}.629^{+} \\
(.347)\end{array}$ & $\begin{array}{r}.317 \\
(.543)\end{array}$ & $\begin{array}{r}.443 \\
(.439)\end{array}$ \\
\hline Relative size of excluded groups & $\begin{array}{r}1.186 * * \\
(.370)\end{array}$ & $\begin{array}{r}2.262 * * * \\
(.654)\end{array}$ & $\begin{array}{r}.760^{+} \\
(.420)\end{array}$ \\
\hline Polity index (lagged) & $\begin{array}{r}.015 \\
(.017)\end{array}$ & $\begin{array}{r}-.024 \\
(.034)\end{array}$ & $\begin{array}{r}.021 \\
(.020)\end{array}$ \\
\hline Population size (logged) & $\begin{array}{r}.235 * * * \\
(.066)\end{array}$ & $\begin{array}{r}-.170 \\
(.125)\end{array}$ & $\begin{array}{r}.392 * * * \\
(.078)\end{array}$ \\
\hline GDP per capita (lagged, logged) & $\begin{array}{r}-.137 \\
(.111)\end{array}$ & $\begin{array}{r}-.180 \\
(.199)\end{array}$ & $\begin{array}{r}-.104 \\
(.139)\end{array}$ \\
\hline Ethnic conflict history & $\begin{array}{r}.233 * * * \\
(.053)\end{array}$ & $\begin{array}{l}.174 * \\
(.085)\end{array}$ & $\begin{array}{r}.174 * * \\
(.060)\end{array}$ \\
\hline State age & $\begin{array}{r}-.001 \\
(.002)\end{array}$ & $\begin{array}{r}.001 \\
(.002)\end{array}$ & $\begin{array}{r}-.001 \\
(.002)\end{array}$ \\
\hline Largest group size & $\begin{array}{r}-.036 \\
(.491)\end{array}$ & $\begin{array}{r}-.827 \\
(.775)\end{array}$ & $\begin{array}{r}.424 \\
(.670)\end{array}$ \\
\hline Number of dispersed ethnic groups & $\begin{array}{r}-.021 \\
(.061)\end{array}$ & $\begin{array}{r}-.001 \\
(.145)\end{array}$ & $\begin{array}{r}-.027 \\
(.044)\end{array}$ \\
\hline Peace years & $\begin{array}{r}-.055 \\
(.048)\end{array}$ & $\begin{array}{r}-.073 \\
(.075)\end{array}$ & $\begin{array}{r}-.085^{*} \\
(.041)\end{array}$ \\
\hline Peace years (quadratic) & $\begin{array}{r}.003 \\
(.002)\end{array}$ & $\begin{array}{r}.005 \\
(.004)\end{array}$ & $\begin{array}{r}.002 \\
(.002)\end{array}$ \\
\hline Peace years (cubic) & $\begin{array}{r}-.000 \\
(.000)\end{array}$ & $\begin{array}{r}-.000 \\
(.000)\end{array}$ & $\begin{array}{r}-.000 \\
(.000)\end{array}$ \\
\hline Constant & $\begin{array}{r}-6.417 * * * \\
(1.286)\end{array}$ & $\begin{array}{r}-2.196 \\
(1.929)\end{array}$ & $\begin{array}{r}-9.347 * * * \\
(1.643)\end{array}$ \\
\hline $\mathrm{N}$ & 5,998 & 5,998 & 5,998 \\
\hline Log likelihood & $-565.897 * * *$ & $-226.070 * * *$ & $-389.481 * * *$ \\
\hline
\end{tabular}

Note: Robust standard errors, with clustering on countries, in parentheses. Log-likelihood figures obtained from standard logistic regressions. $* p<0.05, * * p<0.01, * * * p<0.001 .^{+} p \leq 0.1$ 
Figure 1: The stability of group hierarchies and ethnic groups' segmentation

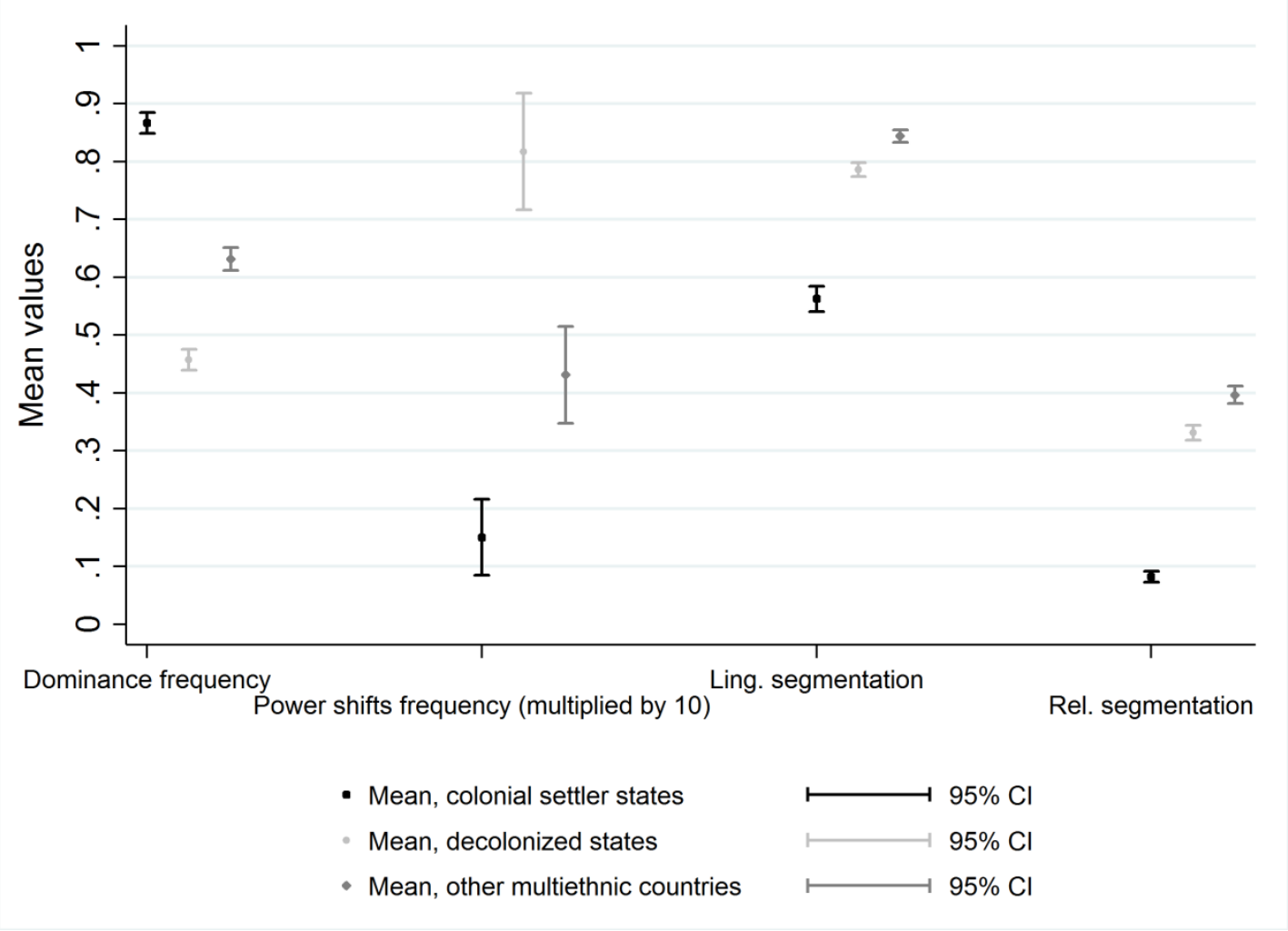

Notes: The figure shows observed frequencies of one-group dominance and ethnic power shifts in the period from 1946 to 2009 , as well as observed linguistic and religious segmentation levels, by state type. Ethnic power shifts values multiplied by 10 to make them compatible with the scale of the other three variables. $95 \%$ confidence intervals derived from two-tailed meancomparison t-tests. The unit of analysis is the country year. 
Figure 2: Rates of ethnic conflict onset by state type, 1946-2009

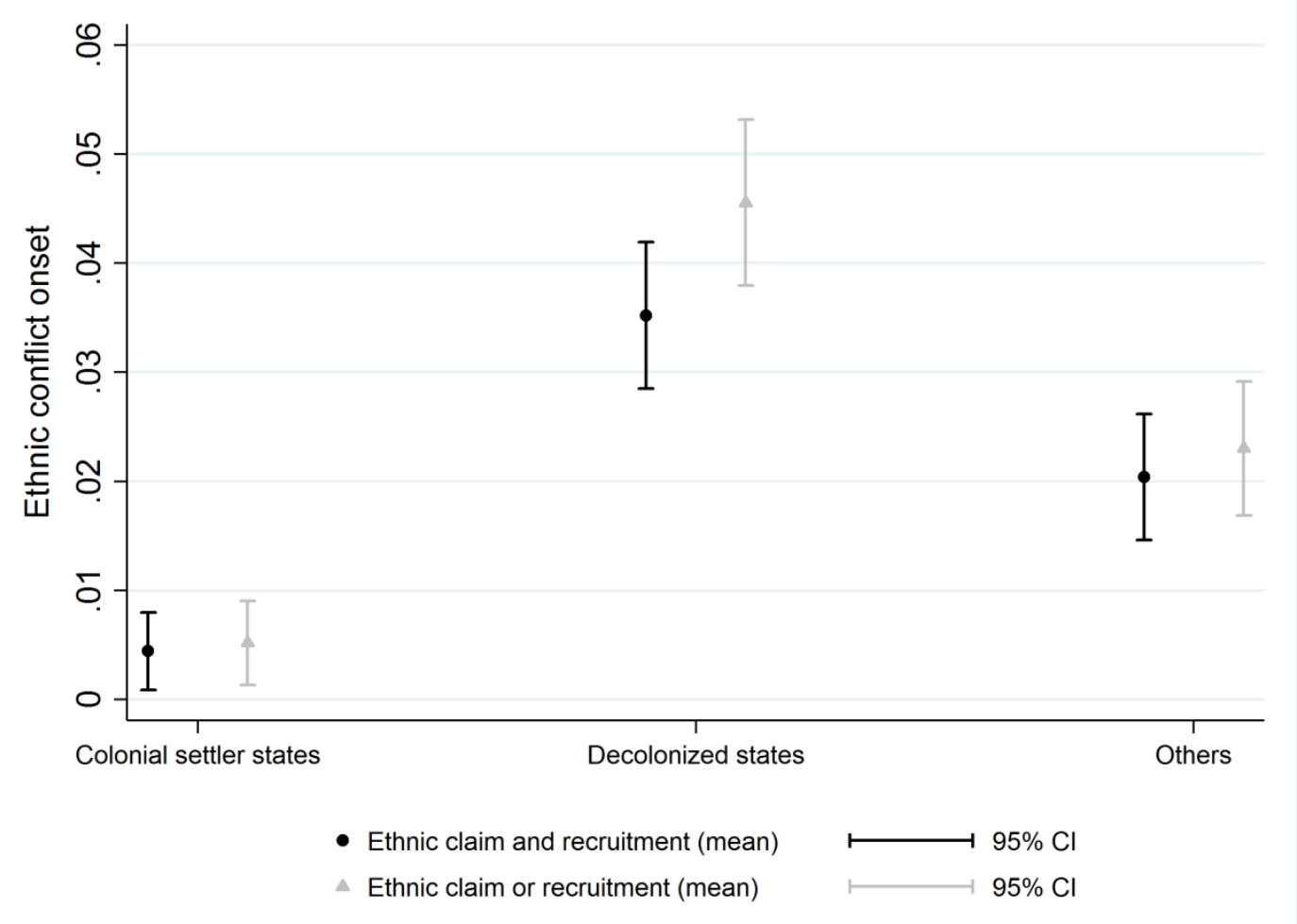

Notes: The figure shows the observed frequencies of ethnic conflict onset, according to the two different definitions, by state type from 1946 to 2009. 95\% confidence intervals derived from two-tailed mean-comparison t-tests. The unit of analysis is the country year. 
Figure 3: Ethnic conflict risk as a function of hierarchization and segmentation

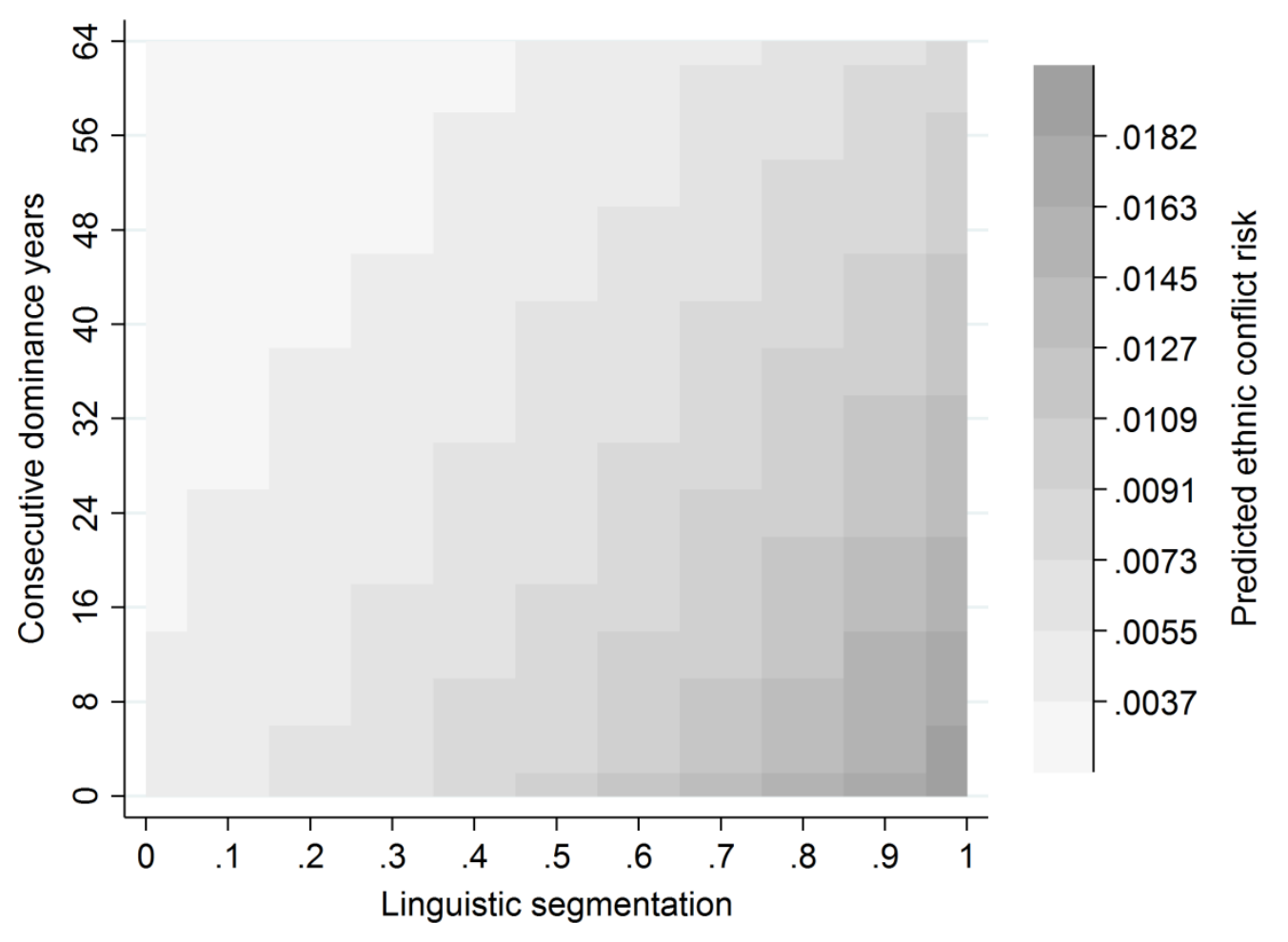

Notes: Based on Model 5 in Table 3, using the "margins" command in Stata 14. Graph shows the predicted ethnic conflict risk as a function of linguistic segmentation and the number of consecutive years of one-group dominance. All other variables held constant at their mean or median. 
Figure 4: Rates of ethnic conflict onset in colonial settler states and decolonized states. Historical comparison

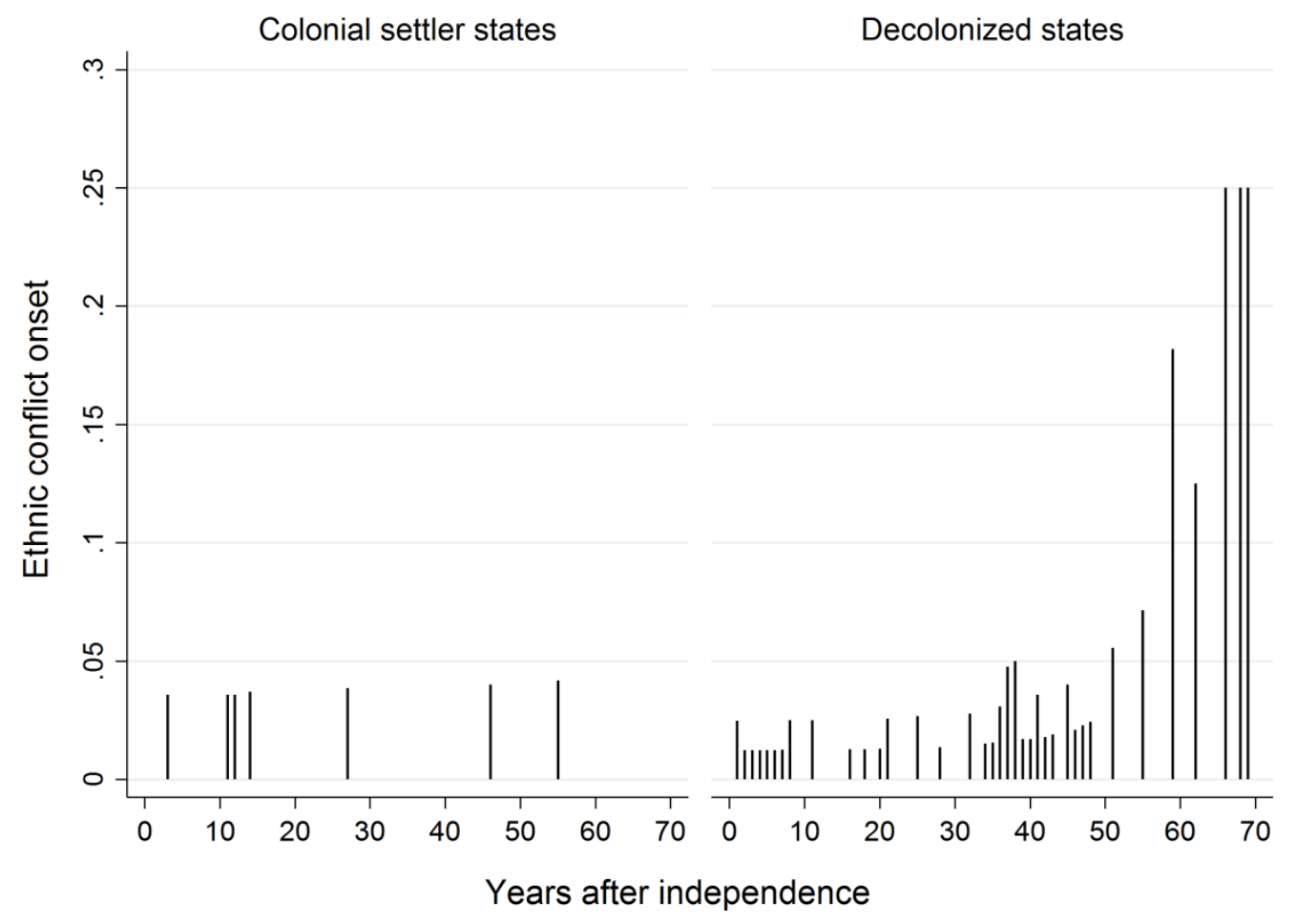

Notes: Calculated based on the COW intrastate dataset and a manual classification of conflicts as ethnic or non-ethnic, according to criteria applied in ACD2EPR dataset. The x-axis represents a count variable of years after independence, rather than the actual calendar year. 